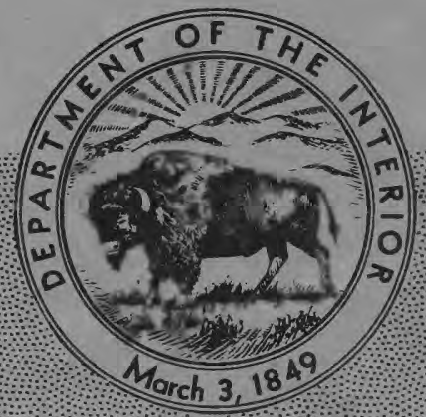

WATER RESOURCES OF THE ROCHESTER AREA

NEW YORK 

UNITED STATES DEPARTMENT OF THE INTERIOR

Douglas McKay, Secretary

GEOLOGICAL SURVEY

W. E. Wrather, Director

GEOLOGICAL SURVEY CIRCULAR 246

\section{WATER RESOURCES OF THE ROCHESTER AREA NEW YORK}

By I, G. Grossman and L. B. Yarger

Washington, D. C., 1953

Free on application to the Geological Survey, Washington 25, D. C. 


\section{CONTENTS}

\begin{tabular}{|c|c|c|c|}
\hline itroduction.. & $\begin{array}{r}\text { Page } \\
1\end{array}$ & Ground water-Continued & Page \\
\hline The Rochester area..................................... & 1 & Drawdown and specific capacity.................. & 22 \\
\hline Topography....................... & 1 & Quality of ground water.......................... & 24 \\
\hline Industry and population................. & 2 & Pollution........................................... & 26 \\
\hline Natural resources............................. & 3 & Temperature.................................. & 26 \\
\hline Climate................... & 3 & Public water-supply systems................. & 26 \\
\hline ources of water.......... & 5 & Rochester.......................... & \\
\hline urface water.......... & 5 & Rochester and Lake Ontario Water Service & \\
\hline Lake Ontario.... & 6 & Corp......................... & \\
\hline Genesee River........................ & 8 & East Rochester.................................. & 28 \\
\hline Black Creek.............................. & 11 & Scottsville..................................... & 27 \\
\hline Honeoye Creek............................. & 15 & Webster..................... & 27 \\
\hline Oatka Creek.................................... & 16 & Pittsford....................................... & 27 \\
\hline Irondequoit Creek................................. & 17 & Present water use....................................... & 27 \\
\hline Other streams................................... & 18 & Use of public supplies............................ & 27 \\
\hline Ground water........................................ & 1.8 & Industrial use..................................... & 28 \\
\hline Waterbearing formations...................... & 20 & Water laws................... & 28 \\
\hline Water-level fluctuations............ & 22 & 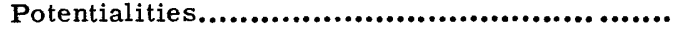 & 28 \\
\hline Yield of wells..................................... & 22 & $\begin{array}{l}\text { Sources of additional information................... } \\
\text { Selected bibliography } \ldots \ldots \ldots \ldots \ldots \ldots \ldots \ldots \ldots \ldots \ldots \ldots\end{array}$ & $\begin{array}{l}29 \\
29\end{array}$ \\
\hline
\end{tabular}

\section{ILLUSTRATIONS}

Plate 1. Map of Rochester area showing surface drainage, culture, and bedrock contours

2. Map of Rochester area showing geologic formations and their waterbearing properties.

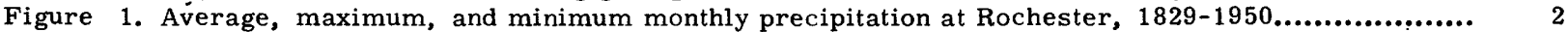

2. Mean monthly snowfall at Rochester, 1885-1950.

3. Maximum and minimum daily and average monthly air temperature at Rochester.....................

4. Duration of published streamflow records in the Rochester area.......................................

5. Maximum, minimum, and average monthly and annual discharge, St. Lawrence River at Ogdensburg, 1919-49

6. Average annual elevation of Lake Ontario, 1860-1951.

7. Average seasonal temperature of Lake Ontario water.................................................

8. Maximum, minimum, and average monthly and annual discharge Genesee River at Rochester, 1920-50

9. Flood profile, Genesee River at Rochester-Central Avenue to Scottsville-West Henrietta road..

10. Flood frequencies, Genesee River at Rochester.......................................................

11. Maximum, minimum, and average monthly and annual discharge Black Creek at Churchville, $1945-50$.

12. Flow-duration curve, Black Creek at Churchville.......................................................

13. Maximum period of deficient discharge without storage, Black Creek at Churchville..................

14. Maximum, minimum, and average monthly and annual discharge, Oatka Creek at Garbutt, $1945-50$.

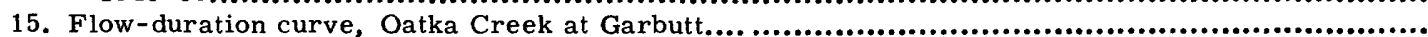

16. Maximum period of deficient discharge without storage, Oatka Creek at Garbutt.......................

17. Estimated flow-duration curve for Irondequoit Creek above barge canal at Bushnell Basin.......

18. Estimated maximum period of deficient discharge without storage, Irondequoit Creek above barge canal at Bushnell Basin.

19. Water levels in observation wells 7385,7397 , and 2040 and monthly precipitation at Scottsville, July 1936 to December 1941 


\section{TABLES}

Table 1. Chemical quality of surface water in the Rochester area..................................................

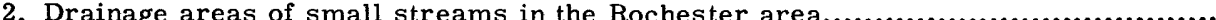

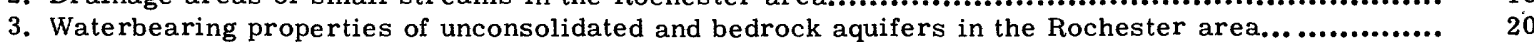

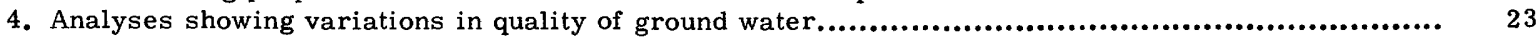

5. Chemical quality of ground waters in the Rochester area.

6. Temperature of ground water in the Rochester area.......................................................

7. Use of water for public supplies. 


\title{
WATER RESOURCES OF THE ROCHESTER AREA, NEW YORK
}

\author{
By I. G. Grossman and L. B. Yarger
}

\section{INTRODUCTION}

An abundant supply of water is available to the Rochester area although local shortages may exist for short periods. Large supplies may be obtained from Lake Ontario and smaller nearby lakes. Smaller supplies, suitable for many municipal and industrial uses, are available from some streams and from the more productive ground-water aquifers. With a properly planned program of development and operation there will be enough water for all anticipated future needs.

A satisfactory water supply is necessary for the economic growth of a region. Cities and towns must have adequate amounts of pure water for domestic use. Industries must have suitable water in sufficient quantities for all purposes. In order to assure success and economy, the development of water resources should be based on adequate knowledge of the present and potential quantity and quality of the water, and the magnitude of its present and future use. As a nation, we cannot afford to run the risk of dissipating our resources, especially in times of national emergency, by building projects that are not founded on sound engineering and adequate water-resources information.

Lake Ontario is a source of a large quantity of water of good quality; therefore, one might think that Rochester's search for water need not go beyond the lake. However, other sources may be more economical for some uses. Lake intakes are expensive, and also, unless the water is to be used at the edge of the lake, an expensive pipeline is required to transport the water to the point of use. Streams, wells, or the public supplies may be the most economical source if the quantity is small or the point of use is some distance from the lake. Water temperature and quality are other factors that must be considered when the most economical source is selected.

This report is intended to provide information of value for national defense and related purposes. It is one of a series concerning water resources of selected areas of strategic importance, prepared under the technical supervision of the Water Utilization Section of the Technical Coordination Branch. This report was prepared under the direct supervision of A. W. Harrington, district engineer (Surface Water); M. L. Brashears, Jr., formerly district geologist (Ground Water); and W. F. White, Jr., district chemist (Quality of Water).
Most of the data summarized in this report have been collected over a period of many years by the U. S. Geological Survey in cooperation with New York State Department of Public Works, Department of Conservation, Water Power and Control Commission, New York State Department of Health, Monroe County Regional Planning Board, and the Corps of Engineers.

Additional data were obtained from industries, local government officials, and individuals. A few of those deserving special mention are J. C. Haberer, district sanitary engineer, New York State Department of Health; J. O'Day, engineer, the New York Water Service Corporation; P. F. Stephens, engineer, Monroe County Department of Public Works; and H. A. Zollweg, engineer, Rochester. Earlier reports have been freely drawn upon and are named in the list of references at the end of this report.

The purpose of this report is to summarize and interpret all available water-resources information for the Rochester area. The report will be useful for initial guidance in the location or expansion of water facilities for defense and nondefense industries and the municipalities upon which they are dependent. No attempt has been made to present a complete record of the hydrologic information for the area.

\section{The Rochester Area}

Rochester is in the west-central part of New York State. As used in this report the Rochester area is that part of Monroe County which lies north and east of Scottsville and includes all of the greater Rochester Metropolitan area (see pl. 1). It has an area of 325 square miles.

\section{Topography}

The altitude of the Rochester area ranges from 246 feet at the shore of Lake Ontario to about 1, 050 feet in the extreme southeast. The topography is marked by a series of three flat plains rising progressively above one another toward the south. Two prominent west-trending ridges or escarpments mark the boundaries of these plains. The Niagara escarpment, underlain by the resistant Lockport dolomite, becomes more pronounced to the west. The Onandaga escarpment crosses the county in the south. The most 


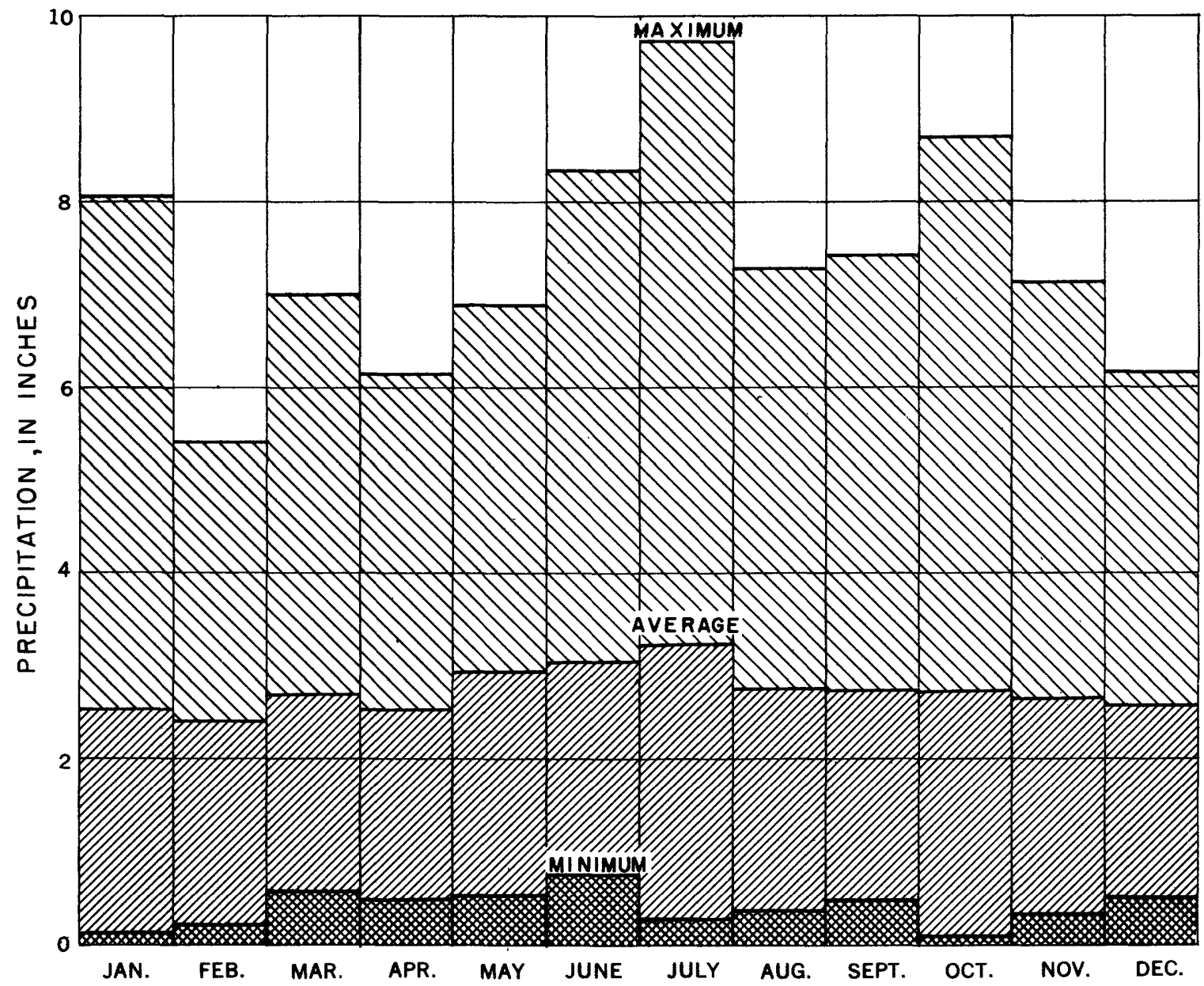

Figure 1.-Average, maximum, and minimum monthly precipitation at Rochester, 1829-1950.

striking topographic feature is the broad valley extending northward through the area to Irondequoit Bay. The entire area drains into Lake Ontario, either directly or through the northward-flowing Genesee River. Most of the county is fairly well drained either by ditches or natural streams (see pl. 1).

\section{Industry and Population}

The Rochester area is strategically situated at the northernmost point of a lowland belt which extends from Buffalo eastward through the Mohawk Valley and contains most of the population of upstate New York. Rochester is a Great Lakes port and a port of entry for foreign trade. Total exports and imports handled by the port of Rochester amounted to $1,261,300$ tons in 1951. The New York State Barge Canal enables goods to reach the port of New York and the sea via the Hudson River. A total of 2,550 canal barges, carrying 440,670 tons, loaded or unloaded at the Rochester terminal during the record season which ended November 30,1951 . A network of radiating roads, including State Routes 96,338 , and 383 link the city to smaller local communities and to adjacent Living- ston, Ontario, and Wayne Counties. Nine bus companies serve Rochester, a major stop on interstate and transcontinental runs. Connections are also made by five railroads which converge upon the city. Darily scheduled airline service is available at the Rochester Municipal Airport.

The population of Monroe County in 1950 was about 485, 000. Rochester, the third largest city in the State, has a population of about 331,000 , while the metropol$i \tan$ area has a population of 484,000 . Some of the larger towns include Greece (population 25, 000), Irondequoit $(34,000)$, and Brighton $(17,000)$. The largest village is East Rochester $(7,000)$, followed by Fairport $(5,000)$. The population density in Monroe County is about 720 persons per square mile.

The Rochester area is one of the leading industrial sections of New York State. The 1951 edition of "Leading industries of Rochester, N. Y., and Monroe County" lists almost 500 industries, most of them in the city of Rochester. More than one-third of the workers are engaged in the production of scientific instruments including cameras, photographic equipment, optical supplies, recording instruments, and 
surgical and dental equipment. Rochester also has a machinery industry which produces electrical equipment, railway signaling systems, farm machinery, pumps, kitchen tools, heating equipment, and indus trial and business machines. Food processing is another important activity. One of the largest fruit belts in the State lies along the shores of Lake Ontario and Monroe County ranked among the top five vegetableproducing counties in 1944. Communities in the lake region cater to the resort as well as to the farmer trade. Rochester is the principal shopping center for nine counties, as is indicated by Monroe County's higher-than-average per capita sales in general merchandise, clothing, and home furnishings.

\section{Natural Resources}

Water is the most important natural resource of the area. The soils which make possible the extensive growing of fruits and vegetables and provide pasture for dairying also form a valuable resource. Additional mineral resources include dolomite, limestone, gypsum, sand and gravel, and natural gas. Road materials and building stones are the most important bedrock products and the Lockport dolomite is the chief source of crushed stone and road material. Gypsum is produced from the upper part of the Camillus shale which underlies the southern part of Monroe County. More than 100 sand and gravel pits have been recorded in the county, but many have been operated only inter- mittently. The only gas pool in Monroe County is in the town of Riga which lies outside the area considered in this report. A small but steady yield of gas has been obtained from the Albion sandstone ("Medina sandstone" of local usage) at Riga.

\section{Climate}

Meteorological data have been collected in Rochester since 1830 . The average annual precipitation at Rochester from 1830 to 1950 inclusive is 32.86 inches. The precipitation varies from month to month as shown in figure 1. The records show that the greatest precipitation generally occurs in summer and the least in winter. The greatest precipitation recorded in any one month was 9.70 inches in July 1947; the least was 0.08 inche in October 1924.

The average annual snowfall at Rochester from 1885 to 1950 inclusive is 75.1 inches. February has the highest average monthly snowfall (18.6 inches), although the maximum in any month was 54.0 inches in March 1900 and the maximum for 24 hours was 29.8 inches in March 1900. Mean monthly snowfall at Rochester for the period 1885 to 1950 is shown in figure 2.

The average temperature for the period 1830 to 1950 was $47.8^{\circ} \mathrm{F}$. The range in temperature within a year is usually about $90^{\circ} \mathrm{F}$. Maximum and minimum daily and average monthly air temperatures are shown in figure 3.

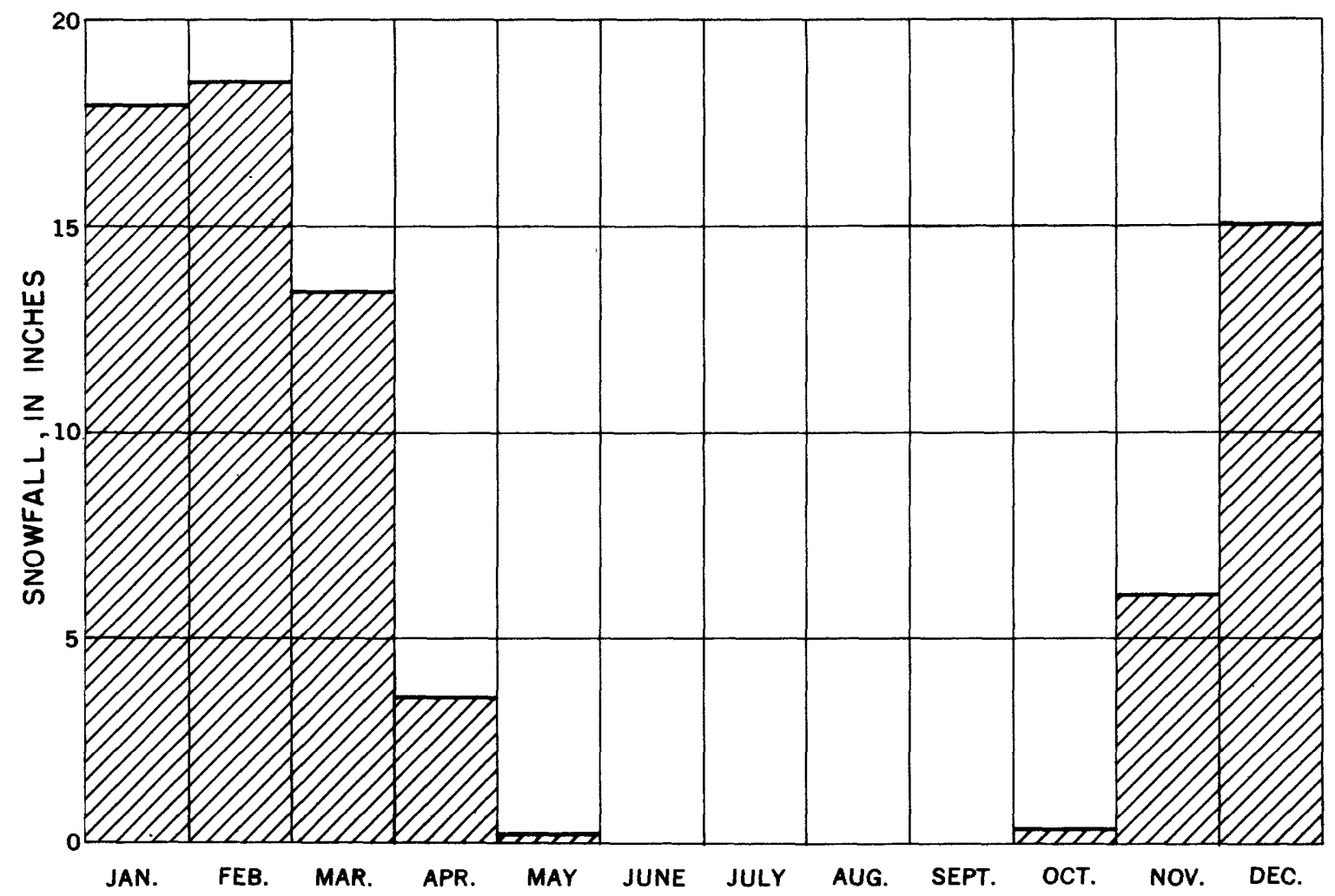

Figure 2.-Mean monthly snowfall at Rochester, 1885-1950. 
WATER RESOURCES OF THE ROCHESTER AREA, N. Y.

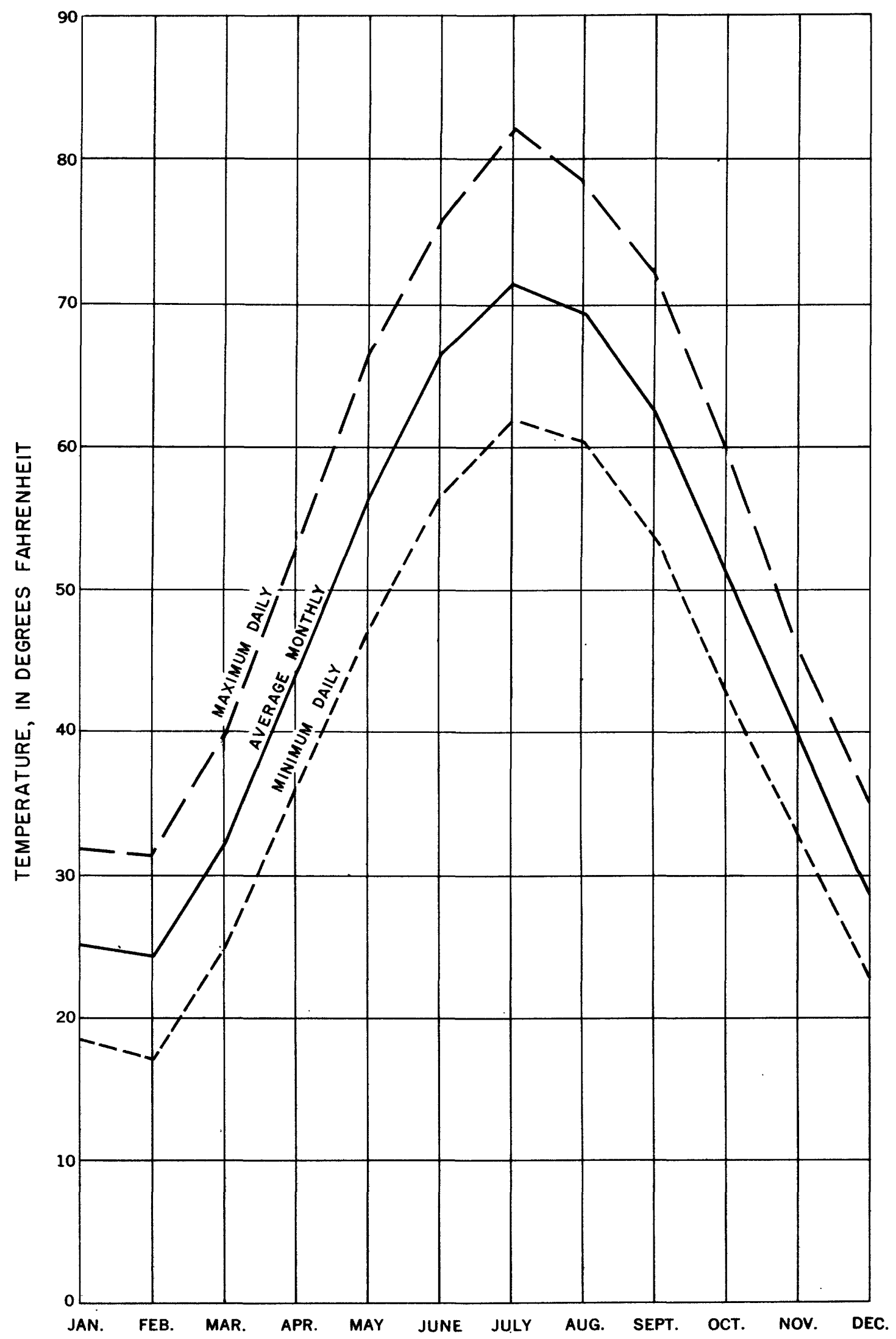


The highest average monthly air temperature generally occurs in July (average $71.2^{\circ} \mathrm{F}$ ) and the lowest, in February (average $24.8^{\circ} \mathrm{F}$ ). The highest mean temperature for any month was $80.7^{\circ} \mathrm{F}$ in July 1936 and the lowest was $17.2^{\circ} \mathrm{F}$ in February 1934.

\section{SOURCES OF WATER}

Precipitation in the form of rain, snow, hail, and sleet is the source of all the fresh water. Part of this precipitation is evaporated or transpired by plants and part of it soaks into the ground or runs off to become streamflow. Subsurface water which is not held by capillary action or lost by evapotranspiration moves downward to the ground-water table. Part of this ground water is withdrawn from wells but most of it escapes through surface or subsurface openings to the lakes and streams which drain to the sea. The evaporation of sea water and its subsequent precipitation on the land completes the hydrologic cycle.

Because of the large quantity of water stored in Lake Ontario, the Rochester area is not dependent on local precipitation for its principal water supply. It has available the accumulated runoff from a $295,000-$ square-mile area upstream from the outlet of Lake Ontario. Smaller lakes and streams provide more moderate supplies for areas some distance from Lake Ontario. The most important streams are the Genesee River, Oatka Creek, Black Creek, and Irondequoit Creek. These supplies and most subsurface supplies are largely dependent on local precipitation.

\section{SURFACE WATER}

Surface water available within the area is sufficient for all present uses and all forseeable future needs. The storage capacity of Lake Ontario, together with the other Great Lakes lying above it, moderates the flow at the outlet and obviates the need for reservoirs to regulate the flow. The chemical character of water from the larger bodies of water is generally good. However, except for the Genesee River, waste-disposal practices have generally had an adverse effect on the streams.

\begin{tabular}{|c|c|c|c|c|c|c|}
\hline \multicolumn{2}{|c|}{ WATER $Y$} & ENDING & SEPTEMBER & 30 & \multirow{2}{*}{$\begin{array}{l}\text { DRAINAGE AREA, } \\
\text { IN SQUARE MILES }\end{array}$} & \multirow{2}{*}{$\begin{array}{l}\text { GAGING } \\
\text { STATION }\end{array}$} \\
\hline $1901-10$ & $1911-20$ & $1921-30$ & $1931-40$ & $1941-50$ & & \\
\hline & & & & & 309 & Genesee River at Scio \\
\hline & & & & & 982 & $\begin{array}{c}\text { Genesee River at } \\
\text { Portageville }\end{array}$ \\
\hline & & & & & 1017 & Genesee River at St. Heleno \\
\hline & & & & & 1078 & Genesee River at Mount Morris \\
\hline & & & & & 1419 & $\begin{array}{c}\text { Genesee River af Jones Bridge, } \\
\text { near Mount Marris }\end{array}$ \\
\hline & & & . & & 2450 & Genesee River at Rochester \\
\hline & & & & & 2467 & $\begin{array}{c}\text { Genesee River at Driving } \\
\text { Park Avenue, Rochester }\end{array}$ \\
\hline & & & & & 61.5 & Coneodeo Creek of Coneodeo \\
\hline & & & & & & $\begin{array}{l}\text { Lost Notion Brook } \\
\text { near Centerville }\end{array}$ \\
\hline & & & & & 153 & $\begin{array}{c}\text { Canaseroga Greek } \\
\text { near Dansville }\end{array}$ \\
\hline & & & & & 155 & $\begin{array}{c}\text { Canaseraga Creek at } \\
\text { Cumminsville }\end{array}$ \\
\hline & & & & & 181 & $\begin{array}{c}\text { Canoserago Creek of } \\
\text { Groveland Station }\end{array}$ \\
\hline & & & & & 69.1 & $\begin{array}{l}\text { Keshequa Creek of } \\
\text { Craig Colony, Sonyed }\end{array}$ \\
\hline & & & & & 76.5 & Keshequo Creek near Sonyea \\
\hline & & & & & 72.0 & Caneous Creek near Lakeville \\
\hline & & & & & 197 & Honeoye Creek at Honeoye Falls \\
\hline & & & & & 208 & Oatko Creek af Garbutt \\
\hline & & & & & 123 & Black Creek af Churchville \\
\hline & & & & & 298,100 & $\begin{array}{l}\text { St. Lawrence River, at. } \\
\text { Ogdensburg,N.Y. }\end{array}$ \\
\hline
\end{tabular}

Figure 4.-Duration of published streamflow records in the Rochester area. 
The most important source of water within the area is Lake Ontario; however, smaller lakes and some streams are of considerable importance. Streamflow records have been collected by the U. S. Geological Survey at several sites within or near the area (fig. 4).

Streamflow records on Black Creek and Oatka Creek are of short duration (records began in 1945). An accurate determination of the flow over a longer period is more useful. In the absence of a long-term record at the desired point it is possible to extend the usefulness of a short-term record at that site by comparison with a longer record for a nearby site. One method of comparison is by the use of flow-duration curves. A flow-duration curve is a chart that shows the cumulative frequency of occurrence of different rates of flow at a given point and is prepared by arranging daily flows in order of magnitude and plotting against percentage of time. It indicates the percent of time, within the length of record, during which any given rate of flow was equaled or exceeded.

The slope of the flow-duration curve is a good index of the storage within a basin, including ground-water storage; that is, the flatter the general slope of the curve, the lower the flood peaks and the higher the sustained dry-weather flow. A comparison of flowduration curves for several streams in a drainage basin will show which ones have the highest dryweather flow. Streams having a high dry-weather flow are the best for a source of water supply.

In addition to showing the general flow characteristics of a stream, a flow-duration curve may be used to solve water-supply problems. For example, it might be necessary to know the average number of days per year when the flow of Black Creek at Churchville is less than 2 mgd (million gallons per day). The 5 years of record at Churchville do not include extreme droughts or floods. The period 1921-50 is considered to be more representative; therefore, a curve for that period was computed by correlation with the record for Canaseraga Creek near Dansville. The duration of daily flows for Black Creek at Churchville for the period 1921-50 (fig. 12) shows that a flow of $2 \mathrm{mgd}$ will be equaled or exceeded 98 percent of the time. On the average there could be at least $2 \mathrm{mgd}$ available for 98 percent of the time or for 358 days per year. Therefore, an industry could obtain a flow of $2 \mathrm{mgd}$ from Black Creek at Churchville with the expectation that on the average there would be a shortage on only 7 days per year.

It may be impossible to operate the plant for short periods on less than $2 \mathrm{mgd}$. However, it is necessary to know the maximum number of consecutive days even in unusual years, that the flow will be less than $2 \mathrm{mgd}$. The flow of Black Creek at Churchville may be expected to be less than $2 \mathrm{mgd}$ for not more than 28 consecutive days (estimated curve 1921-50, fig. 13).

\section{Lake Ontario}

Lake Ontario, the smallest of the Great Lakes, has an area of 7,540 square miles. The shape of the lake is oval and the longest axis lies in the east-west direction. It is about 190 miles long and has a maximum width of about 60 miles. The lake is relatively shallow near the shore. One mile offshore the depth is only about 40 feet compared to a depth of 100 feet about 2 miles offshore. The greatest depth sounded is 778 feet. Fluctuations of the lake surface due to winds are reduced materially because of this great depth.

The drainage area tributary to the lake at its head is 263,500 square miles and an additional area of

Table 1.-Chemical quality of surface water in Rochester area

[Dissolved constituents given in parts per million]

\begin{tabular}{|c|c|c|c|c|c|c|}
\hline Source & $\begin{array}{c}\text { Genesee River } \\
\text { at } \\
\text { Rochester }\end{array}$ & $\begin{array}{c}\text { Riverview Heights } \\
\text { Water Association, } \\
\text { Genesee River }\end{array}$ & \begin{tabular}{|l|} 
Hemlock \\
Lake, \\
Rochester
\end{tabular} & $\begin{array}{c}\text { Lake } \\
\text { Ontario, } \\
\text { Rochester }\end{array}$ & $\begin{array}{c}\text { Lake Ontario } \\
\text { (treated), } \\
\text { Rochester }\end{array}$ & \begin{tabular}{|c|} 
New York \\
State \\
Barge Canal
\end{tabular} \\
\hline Silica $\left(\mathrm{SiO}_{2}\right) \ldots \ldots \ldots \ldots \ldots \ldots \ldots \ldots$ & 4.4 & - & 3.5 & 0.9 & 0.1 & - \\
\hline Manganese $(M n) \ldots \ldots \ldots \ldots \ldots . . . . . . .$. & 0.00 & - & .00 & .00 & .00 & - \\
\hline Calcium (Ca)......................... & 58 & 188 & 22 & 38 & 39 & - \\
\hline Magnesium (Mg)................... & 12 & 66 & 5.8 & 8.3 & 8.3 & - \\
\hline Bicarbonate $\left(\mathrm{HCO}_{3}\right) \ldots \ldots \ldots \ldots . . . .$. & 131 & 122 & 59 & 110 & 107 & - \\
\hline Sulfate $\left(\mathrm{SO}_{4}\right) \ldots \ldots \ldots \ldots \ldots \ldots$ & 82 & 116 & 26 & 25 & 30 & - \\
\hline Chloride (Cl)...................... & 33 & 121 & 5 & 23 & 23 & 25 \\
\hline 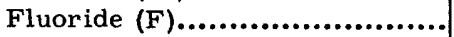 & 0.2 & - & .0 & .0 & .0 & - \\
\hline Nitrate $\left(\mathrm{NO}_{3}\right), \ldots \ldots \ldots \ldots \ldots \ldots$ & 0.6 & - & 1.0 & .7 & .6 & - \\
\hline Dissolved solids................... & 313 & - & 101 & 171 & 174 & - \\
\hline pH.............................. & 7.6 & 7.2 & 7.4 & 7.7 & 7.3 & - \\
\hline Specific conductance in & & & & & & \\
\hline micromhos at $25^{\circ} \mathrm{C} \ldots . .$. & 477 & - & $\therefore \quad 170$ & ․․ $\quad 297$ & 302 & 431 \\
\hline Date of collection.............. & $6-20-51$ & $11-16-44$ & $6-20-51$ & $6-20-51$ & $6-20-51$ & $6-20-51$ \\
\hline
\end{tabular}




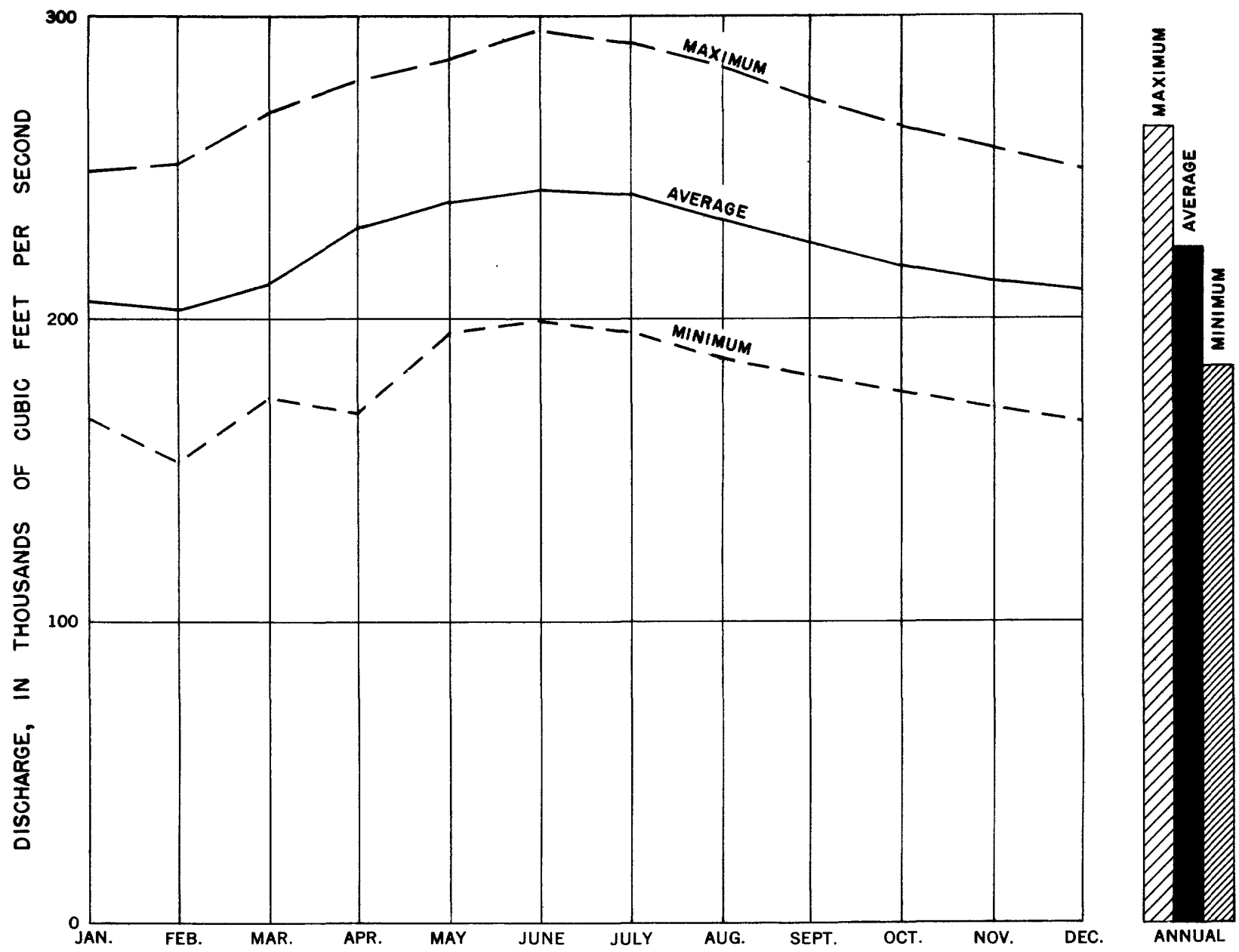

Figure 5. -Maximum, minimum, and average monthly and annual discharge, St. Lawrence River at Ogdensburg $(1919 .-49)$.

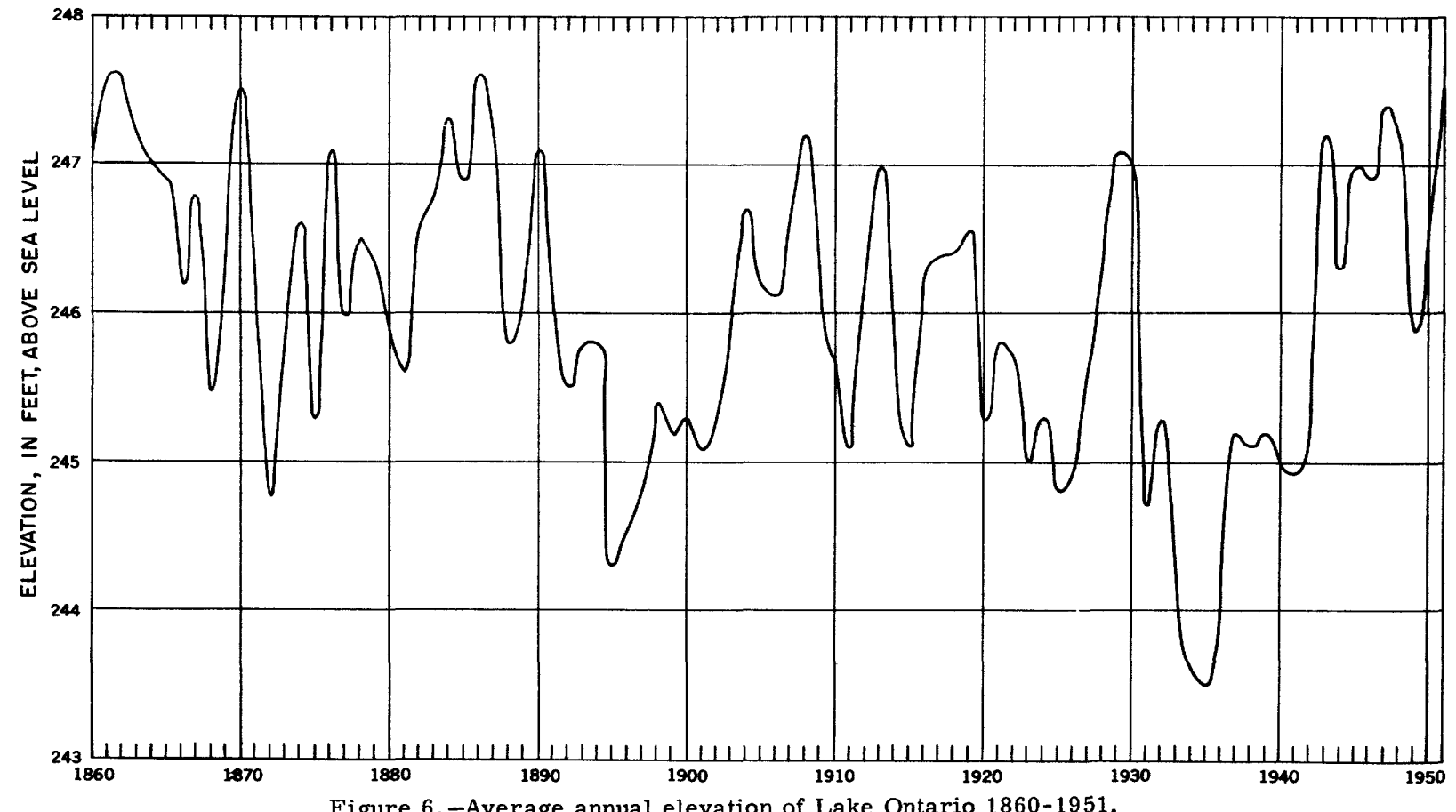


about 32,000 square miles drains directly into the lake. A gaging station has been maintained on the St. Lawrence River at Ogdensburg, N. Y., by the Corps of Engineers since January 1919. For all practical purposes the water available at Rochester may be considered equal to the flow of the St. Lawrence River at Ogdensburg. The average flow for 31 years, October 1918 to September 1949, was 226, 000 cfs (cubic feet per second). The maximum, minimum, and average monthly and annual flow of the St. Lawrence River at Ogdensburg are shown in figure 5.

Lake elevations have been recorded since 1860 by the U. S. Lake Survey, Corps of Engineers. The average elevation for the 50-year period, 1900 to 1949, was 245. 75 feet above mean sea level at New York. Figure 6 shows the average annual elevation of the lake for the period 1860 to 1951 . The greatest difference between the highest and lowest monthly mean for any year is 3.20 feet and the smallest difference is 0.69 foot. The difference between the highest and lowest monthly mean elevation (1860 to 1951) is 6.29 feet.

Rochester (Charlotte) Harbor is at the mouth of the Genesee River, 7 miles downstream from Rochester. The Corps of Engineers maintains a river channel 20 feet deep and about 150 feet wide in the lower 2.2 miles of the river. The navigation season extends from about April 15th to about December 15th.

The quality of Lake Ontario water is excellent except that it is moderately hard. Two samples, one of untreated lake water and one of treated lake water were collected and analyzed during the summer of 1951. Results of the analysis are given in table 1.

The lake receives some domestic and industrial pollution. Part of the sewage from the city of Rochester receives primary treatment at Durand Eastman
Park and is discharged into the lake through an outlet extending 7, 500 feet offshore. The remainder of the sewage from Rochester and sewage from adjacent towns receives either primary or secondary treatment before discharge into the Genesee River or smaller streams tributary to the lake.

The Eastman Kodak Company has recorded the temperature of Lake Ontario water since 1928. The average temperature for the 21-year period, 1928 to 1948, was $47.5^{\circ} \mathrm{F}$. The highest mean 24 -hour temperature was $75.7^{\circ} \mathrm{F}$ and the lowest was $32^{\circ} \mathrm{F}$. Figure 7 shows the average seasonal temperature of Lake Ontario water.

\section{Genesee River}

The Genesee River is the largest stream in the area. It rises at an elevation of 2,395 feet in Potter County, $\mathrm{Pa} .$, and flows northwestward for 40 miles before turning northeastward to Lake Ontario. The river is about 160 miles long and its basin is about 100 miles from north to south by 40 miles east to west. The drainage area at its mouth is 2,476 square miles. The upper part of the river basin is hilly and partly wooded. The river flows through a deep and narrow canyon from Portageville to Mount Morris and descends about 500 feet in this 20 -mile reach. Below Mount Morris the river meanders through an alluvial plain from 1 to 3 miles wide. At Rochester it drops over the Niagara escarpment with a total fall of 260 feet.

Several lakes in the Genesee River basin serve as natural reservoirs. Honeoye, Canadice, and Hemlock Lakes are tributary to the Genesee River through Honeoye Creek, Conesus Lake through Conesus Creek, and Silver Lake through Silver Lake Outlet.

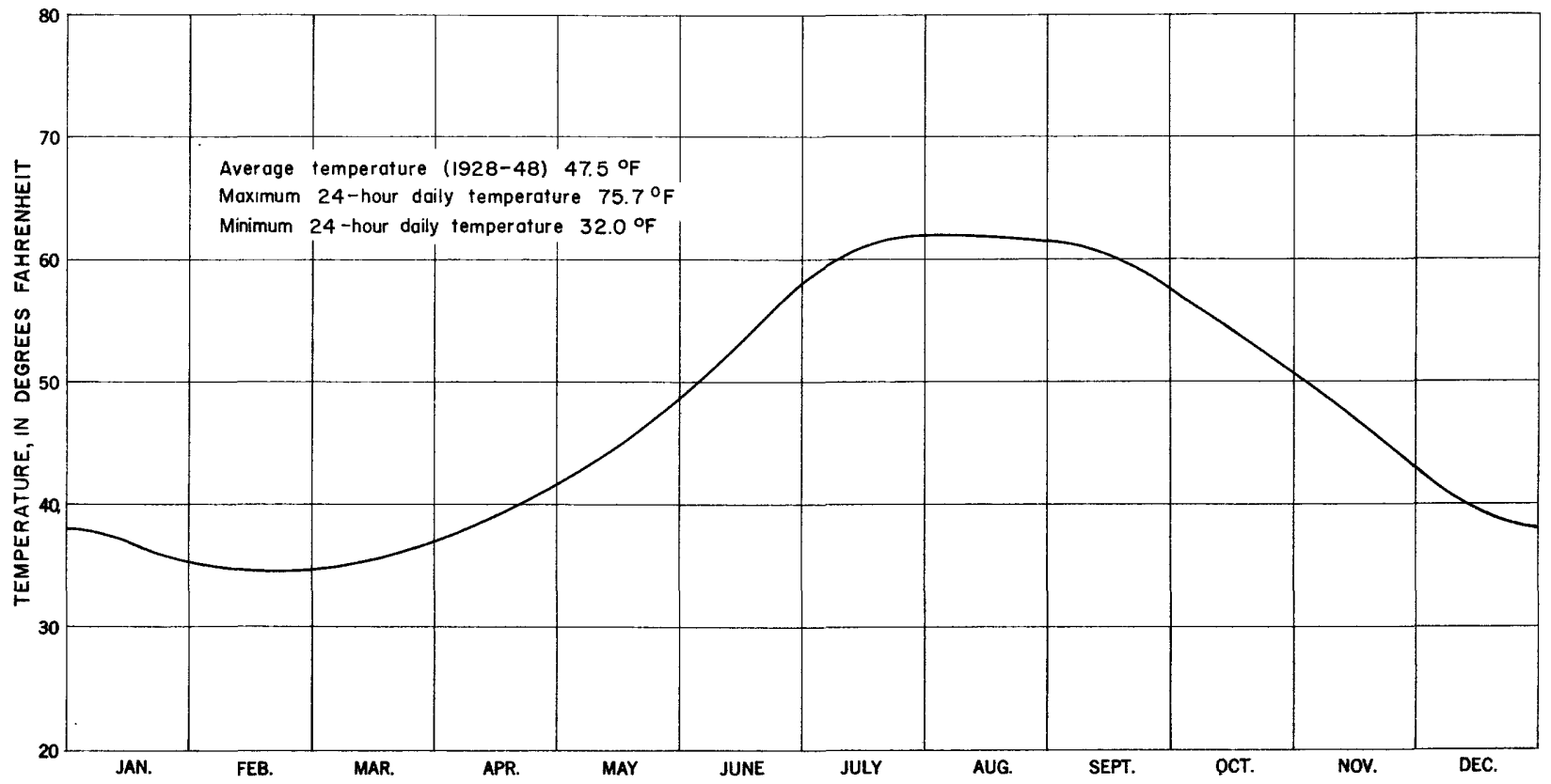

Figure 7.-Average seasonal temperature of Lake Ontario water. 


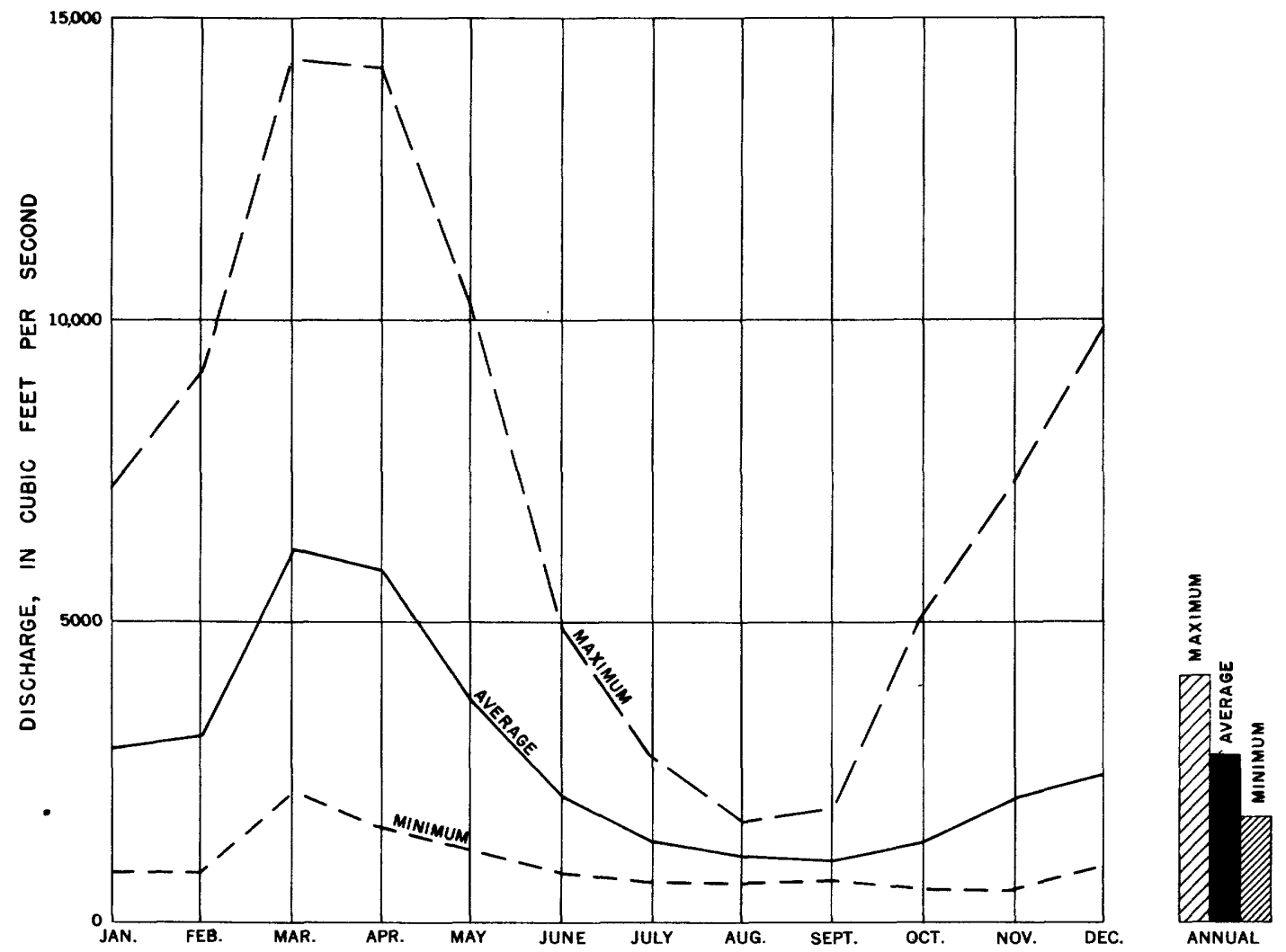

Figure 8.-Maximum, minimum, and average monthly and annual discharge Genesee River at Rochester, 1920-50.

The construction of Mount Morris Dam by the Corps of Engineers at a point 40 miles upstream from Rochester was completed in 1951. This dam provides temporary storage of flood waters which annually caused much damage to farm land and residential areas in the valley between Mount Morris and Rochester. Under normal operations the reservoir will hold only flood flow in excess of the capacity of the river channel. When full, the reservoir will have a storage capacity of 337,000 acre-feet, equal to 6 inches of runoff from the 1,077 square miles of drainage area above the dam. Stored flood waters are to be released gradually through nine conduits each having a capacity of $2,700 \mathrm{cfs}$. Continuous discharge for at least 16 days will be required to empty the full reservoir without flood danger to the lower reaches of the valley.

There has been no navigation on most of the Genesee River since the Genesee canal was abandoned in 1877. The New York State Barge Canal crosses the river at river level at the southern edge of Rochester. The Genesee is navigable for barge traffic from the canal to the State dam near the Court Street bridge. The Genesee River is navigable for lake boat traffic 2.2 miles above its mouth but no waterway connects the barge canal with the Rochester Harbor. the area have been collected and published. (See fig. 4.) Records were collected at the Elmwood Avenue bridge, drainage area 2, 450 square miles, from February 1904 to September 1918, and at the Driving Park Avenue bridge, drainage area 2,467 square miles, since December 1919. The flow at Driving Park Avenue bridge is affected by diurnal fluctuations caused by power plants above the station. Caneadea Reservoir, Conesus, Hemlock, Canadice, and Honeoye Lakes also regulate the flow. During the navigation season on the New York State Barge Canal, about $600 \mathrm{cfs}$ is diverted from Lake Erie into the Genesee River through the barge canal. A large part of the present public water supply for Rochester is obtained from Canadice and Hemlock Lakes. The estimated usable storage capacity of the two lakes is $1,500 \mathrm{mil}-$ lion cubic feet (11.2 billion gallons).

Average flow, -Average discharge at Driving Park Avenue bridge for the 30 -year period (October 1920September 1950) was $2,753 \mathrm{cfs}$ including water diverted from Lake Erie. Maximum, minimum, and average monthly and annual discharge for the period of record is shown in figure 8.

Minimum flow. -The minimum daily flow at this site for the period December 1919 to September 1950 was $219 \mathrm{cfs}$ on August 14, 1927. A flow of less than $10 \mathrm{cfs}$ has occurred for part of a day during low- 


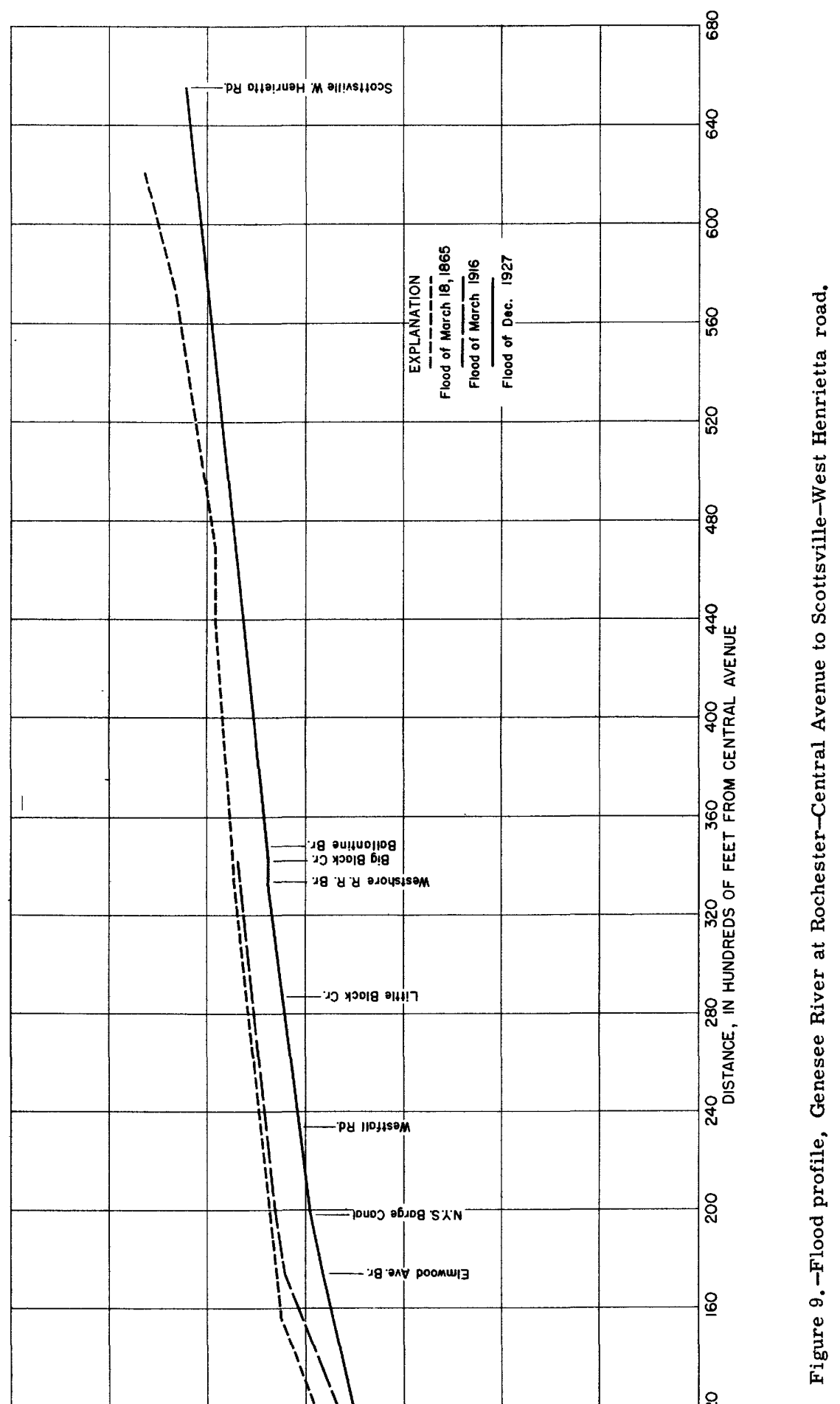


water periods in some years when the power plant above the gaging station was not operating.

Floods. -The earliest flood on the Genesee River of which there is any knowledge occurred in 1785 . Another great flood on October 23, 1835, is recorded as the greatest one known up to that time. The $1835 \mathrm{flood}$ was exceeded on March 18, 1865, when a maximum flow of about $54,000 \mathrm{cfs}$ was recorded. This flood has not been exceeded and is thus the greatest in the 167-year period since 1785 . The maximum flow of the March 28, 1913, flood was $42,000 \mathrm{cfs}$. The greatest flood since 1865 and probably the second greatest flood since 1785 occurred on March 30,1916 . The maximum flow was $48,300 \mathrm{cfs}$. Profiles of the 1865, 1916, and 1927 floods for the section of river between the Central Avenue bridge and the Scottsville-West Henrietta road are shown in figure 9 . This figure shows an appreciable difference in water levels on the upstream and downstream side of the Erie Aqueduct and the Main Street bridge during the 1865 flood. This difference in levels indicates that the structures had a damming. effect on the flow. Four of the seven arches of the aqueduct were more or less obstructed by trees and debris at the crest of the flood. This effect did not occur during the 1916 flood. Under present-day conditions the channel between the Central Avenue bridge and the Erie Aqueduct would carry the same amount of water at a somewhat lower stage because the channel was lowered about 8 feet during the period 1916 to 1919.

The flood-frequency curve (fig. 10) was developed from records of floods collected at both gage sites and all other available authenticated data. The curve may be used to estimate the probability of recurrence of a flood of a given magnitude as long as the river remains unregulated. For example, a flood of the magnitude of the 1916 flood $(48,300 \mathrm{cfs})$ can be expected to occur on the average of once in 81 years and a flood of the magnitude of the 1927 flood can be expected to occur only once in about 6 years. With Mount Morris Dam completed flood crests will be reduced and the recurrence interval for any given flow will be greater (floods of a given magnitude will be less frequent).

Quality. -Genesee River water is of good quality, although it is harder than either Lake Ontario or Hemlock Lake water. Results of the analysis of a sample of water collected during the summer of 1951 are given in table 1 .

Treated sewage from the Rochester sewage treatment plant near Rochester (Charlotte) harbor is discharged into the river after receiving primary treatment. Part of the sewage from the town of Irondequoit also receives primary treatment before being discharged into the Genesee River. Effluent from sewagetreatment plants at Mendon and Scottsville reaches the Genesee River through tributary streams.

\section{Black Creek}

Black Creek rises near'Batavia in Genesee County and flows northeastward, entering the Genesee River about 14 miles from Lake Ontario. The stream is 45 miles long and descends from an elevation of 1,200 feet at its head to 515 feet at its mouth. It drains an

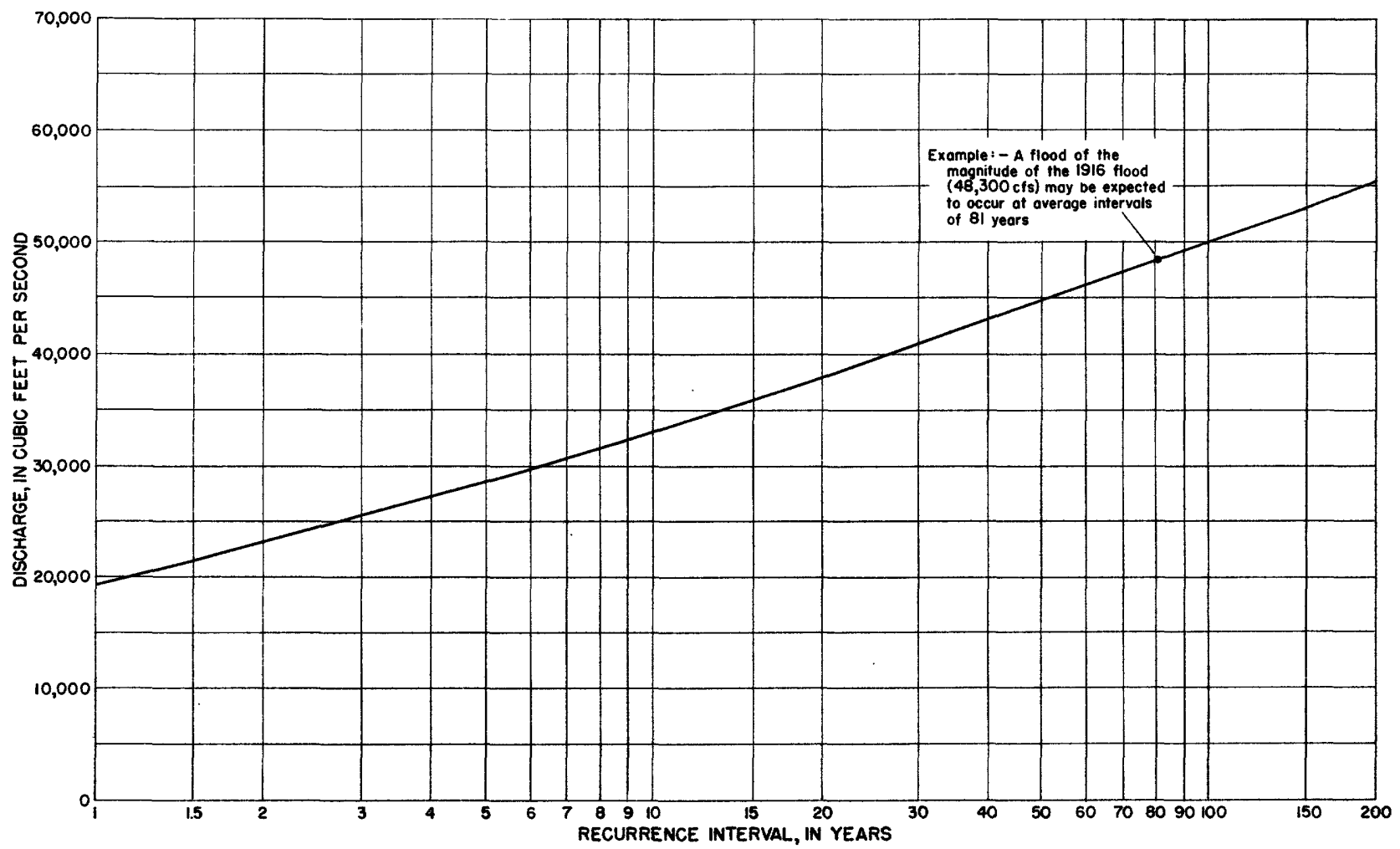

Figure 10-Flood frequencies, Genesee River at Rochester. 


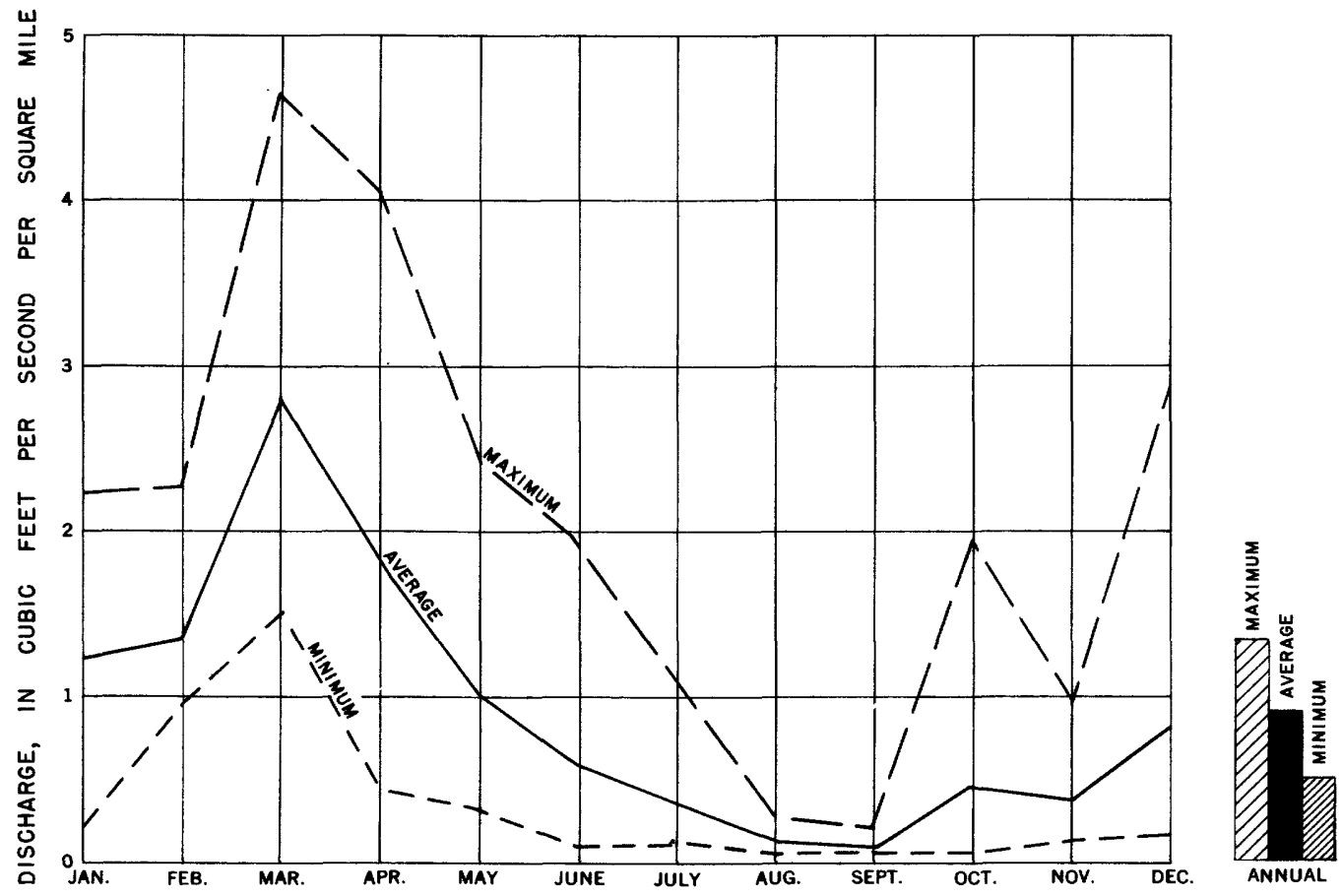

Figure 11.-Maximum, minimum, and average monthly and annual discharge Black Creek at Churchville, $1945-50$.

area of 187 square miles consisting chiefly of farm land and small villages. The villages of Bergen and Churchville are within the basin.

Gaging stations. -Records of stage and discharge at Churchville have been collected and published by the U. S. Geological Survey since October 1945. Datum of gage is 552.45 feet above mean sea level.

Drainage area. -123 square miles.

Average discharge. -5 years $(1945-50) 112 \mathrm{cfs}$. Average discharge. -30 years $(1920-50) 116 \mathrm{cfs}$ (estimated).

Monthly discharge. -The monthly discharge for the period October 1945 to September 1950 ranged from 3.75 to $497 \mathrm{cfs}$. Figure 11 shows the maximum, minimum, and average monthly and annual discharge for the period of record.

Floods. -Black Creek is not subject to excessive flooding but lands along the lower 3 miles of its length are subjected annually to overflow caused by backwater from the Genesee River. No data on floods prior to the establishment of the gaging stations are available.

Peak flows greater than $1,000 \mathrm{cfs}$ during the period of record are as follows:

\section{$\underline{\text { Date }}$}

Oct. 3, 1945

Jan. 7, 1946

Mar. 5, 1946

Mar. 25, 1947

Apr. $\quad 6,1947$

June 4,1947

Feb. 20, 1948

Mar. 1, 1948

Mar. 28, 1950
Discharge (cfs)

1,460

1,240

1,740

1,540

1,940

1,400

1,530

1,100

4,750

Low flows. -The minimum discharge recorded since October 1945 was 0.7 cfs on Sept. 29, 1950. The flowduration curve, figure 12 , and the curve showing maximum period of deficient discharge, figure 13, show the low-flow characteristics of the stream.

Diversions. - The New York Central Railroad diverts approximately $12,300,000$ gallons each month (equivalent to a mean discharge of $0.6 \mathrm{cfs}$ ) from a point just above the station. Records of discharge do not include the diverted flow.

Quality. -Quality and temperature data are not available for this stream. 


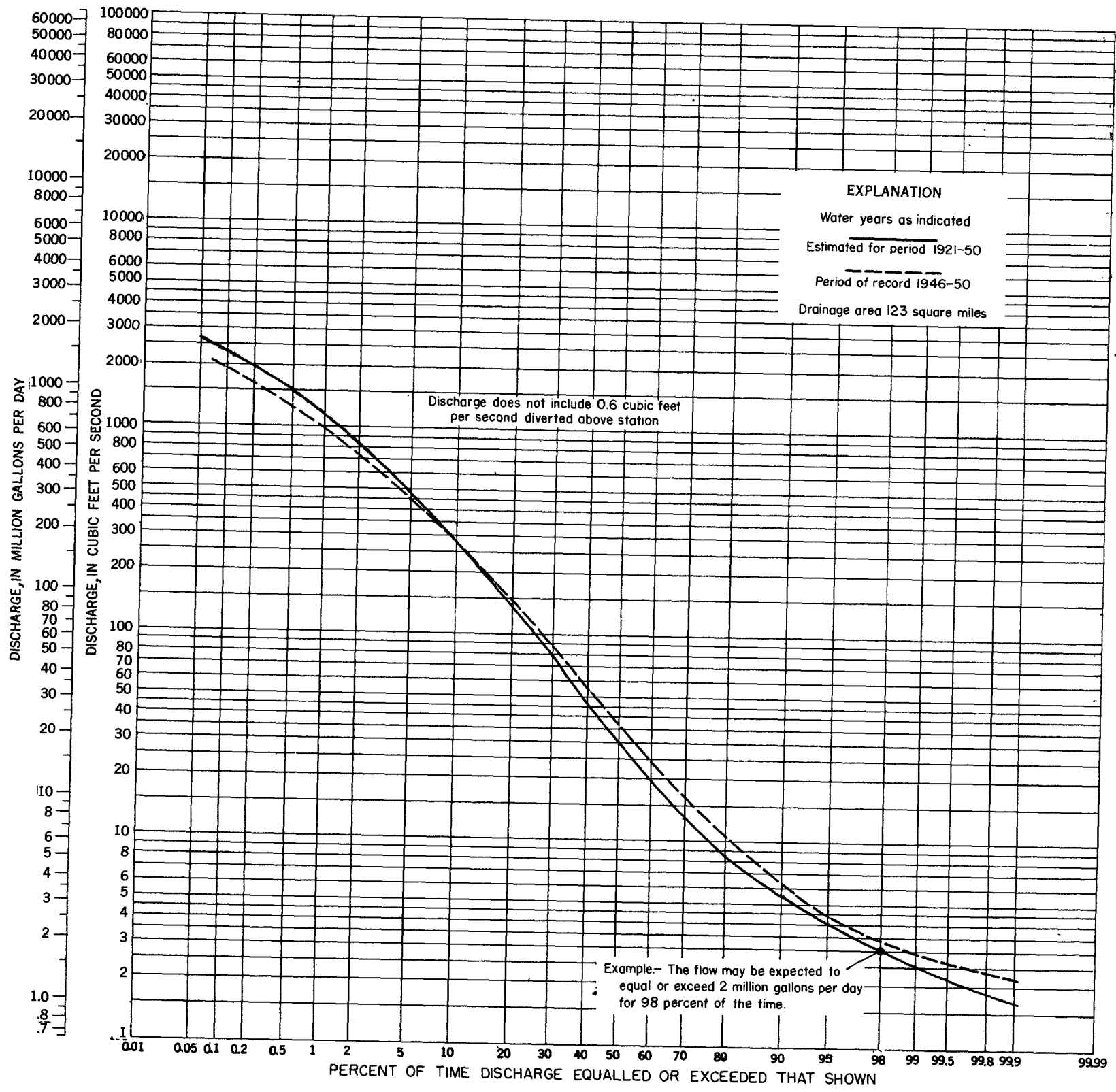

Figure 12, -Flow-duration curve, Black Creek at Churchville. 


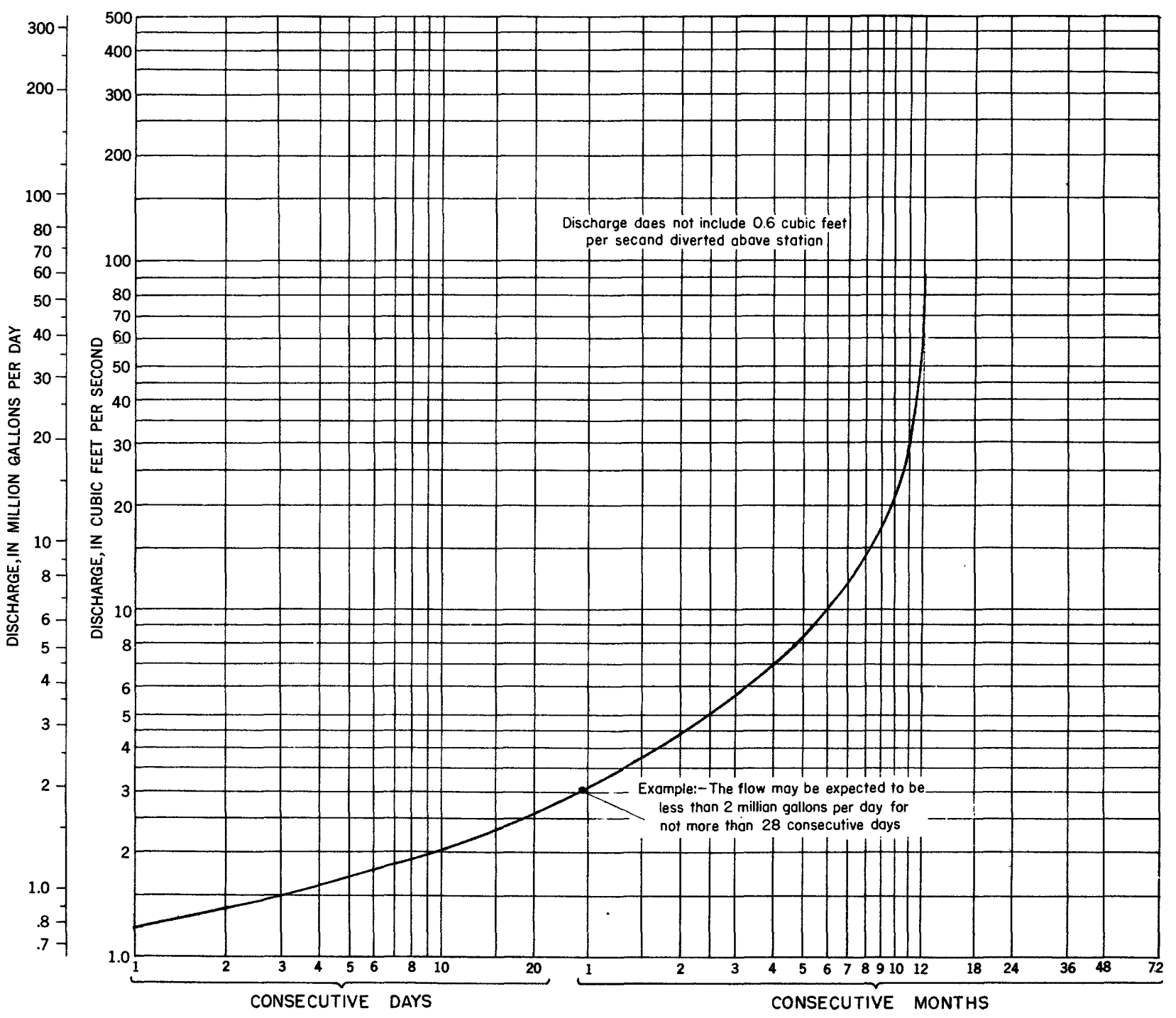

Figure 13. -Maximum period of deficient discharge without storage, Black Creek at Churchville. 


\section{Honeoye Creek}

Honeoye Inlet rises southeast of Honeoye Lake in Ontario County and flows nor thward about 8 miles to Honeoye Lake. From the lake, Honeoye Creek flows northward for 21 miles, then turns and flows westward 9 miles, entering the Genesee River about 26 miles from Lake Ontario. The stream has a total length of 38 miles and descends from an elevation of 1,180 feet to 520 feet. In its course of 8 miles to Honeoye Lake, the stream descends 380 feet. From the lake to the Genesee River the gradient is rather flat and at times backwater from the river extends up Honeoye Creek almost to Rush. It drains an area of 260 square miles part of which is rugged terrain. The villages of Honeoye, Honeoye Falls, and West Bloomfield are within the basin.

Gaging stations. -Records of stage and discharge at Honeoye Falls have been collected and published by the U. S. Geological Survey since October 1945. Datum of gage is 609.98 feet above mean sea level.

\section{Drainage area. -197 square miles}

Average discharge. -5 years (1945-50) $160 \mathrm{cfs}$ (adjusted for diversion from and change in contents in Hemlock and Canadice Lakes).
Monthly discharge. -The monthly discharge for the period October 1945 to September 1950 ranged from 0.75 to $496 \mathrm{cfs}$.

Diversion. -During the period October 1945 to September 1950 the city of Rochester diverted about 57 cfs from Canadice and Hemlock Lakes for water supply.

Floods. -Data on floods prior to the establishment of the gaging station are not available.

Peak flows greater than 1,500 cfs during the period of record are as follows:

\section{$\underline{\text { Date }}$}

Apr. 6,1947

June 3,1947

Mar. 28, 1950

Feb. 22, 1951

Gage height
(feet)

4. 56

4. 71

6.42

4.78
Discharge (cfs)

1,600

1,740

4,630

1,980
Detention in and diversion from the lakes above the gaging station reduce the flood peaks materially.

Low flows. - The minimum discharge recorded since October 1945 is 0.06 cfs on August 28, 1949. Low flows are caused by detention in and diversion from the lakes above the gaging station.

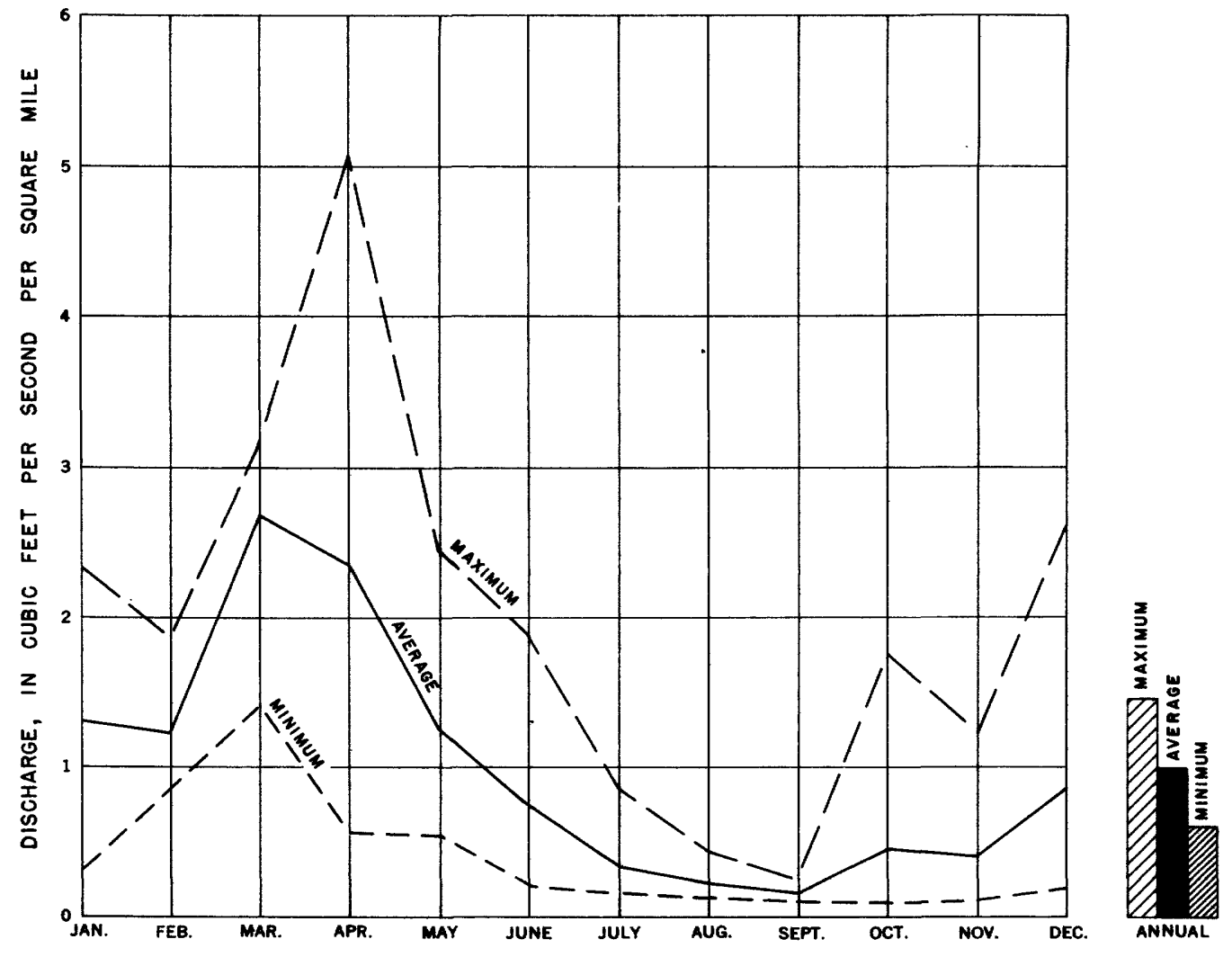

Figure 14. -Maximum, minimum, and average monthly and annual discharge, Oatka Creek at Garbutt, $1945-50$. 
Quality. -The analysis of a sample of Hemlock Lake water collected during the summer of 1951 is given in table 1.

\section{Oatka Creek}

Oatka Creek rises near Warsaw in Wyoming County, and flows northeastward, entering the Genesee River near Scottsville about 22 miles from Lake Ontario. The stream has a length of 52 miles and descends from an elevation of 1,700 feet at its head to 520 feet at its mouth. It drains an area of 215 square miles, consisting chiefly of farm and other rural land. The villages of Warsaw and LeRoy lie within the basin.

Gaging stations. -Records of stage and discharge at Garbutt have been collected and published by the U. S. Geological Survey since October 1945. Datum of gage is 560.89 feet above mean sea level.

Drainage area. -208 square miles.
Average discharge. -5 years $(1945-50) 208 \mathrm{cfs}$.

Average discharge. - vu years (1920-50) $213 \mathrm{cfs}$ (estimated).

Average discharge. -The monthly mean discharge for the period October 1945 to September 1950 ranged from 22.2 to $1,069 \mathrm{cfs}$. Figure 14 shows the maximum, minimum, and average monthly and annual discharge for the period of record.

Floods. -Oatka Creek is not subject to excessive flooding, but lands along its lower mile are subjected to annual overflow caused by backwater from the Genesee River. No data on floods prior to the establishment of the gaging station are available. Peak discharges above 1,500 cfs during period of record are as follows:

\begin{tabular}{lrr} 
Date & $\begin{array}{c}\text { Gage height } \\
\text { (feet) }\end{array}$ & \multicolumn{1}{c}{$\begin{array}{c}\text { Discharge } \\
\text { (cfs) }\end{array}$} \\
\cline { 2 - 2 }, 1946 & 6.63 & 2,830 \\
5,1946 & 5.99 & 2,350 \\
7. 1947 & 6.16 & 2,830
\end{tabular}

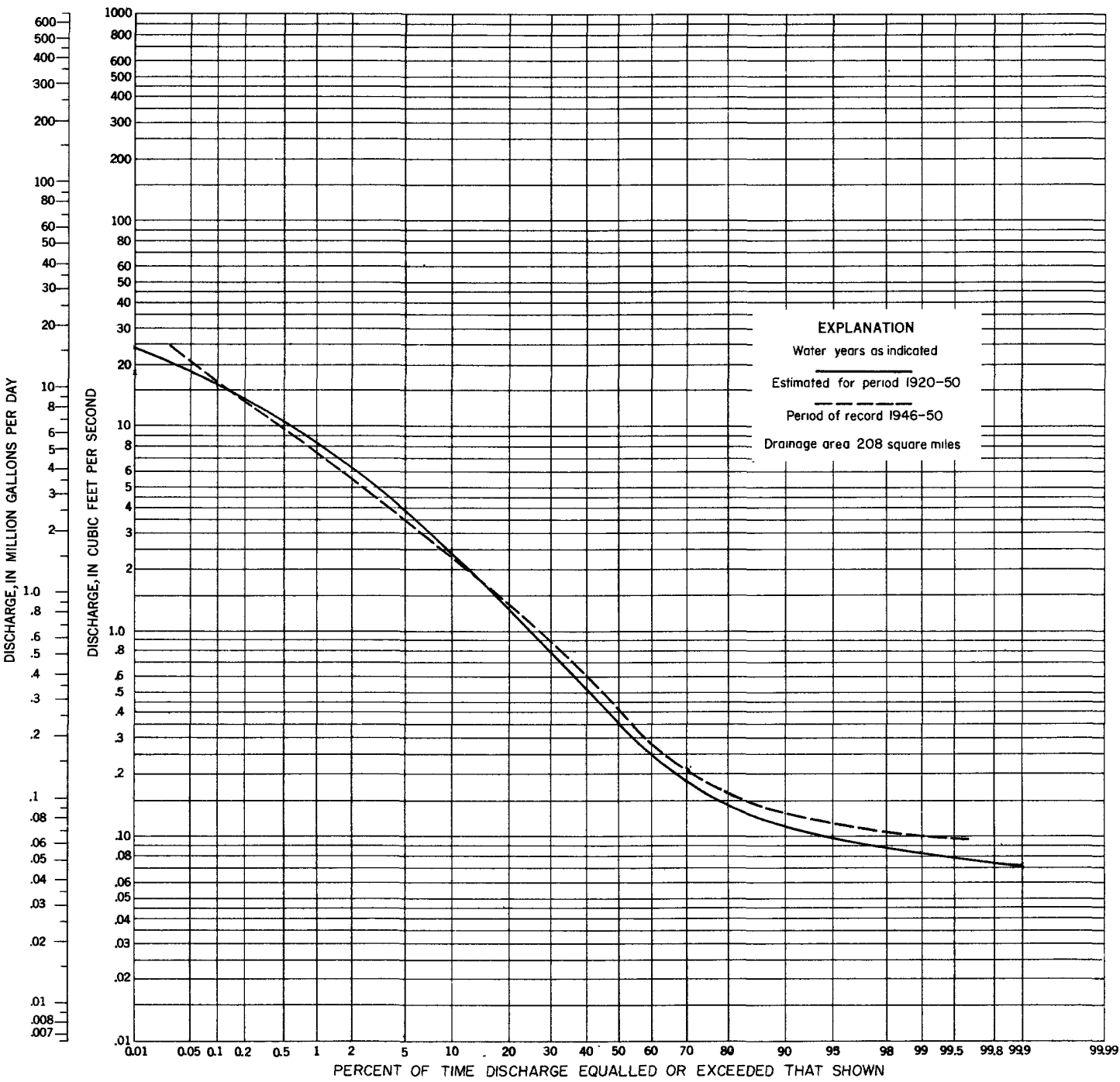

Figure 15.-Flow-duration curve, Oatka Creek at Garbutt. 


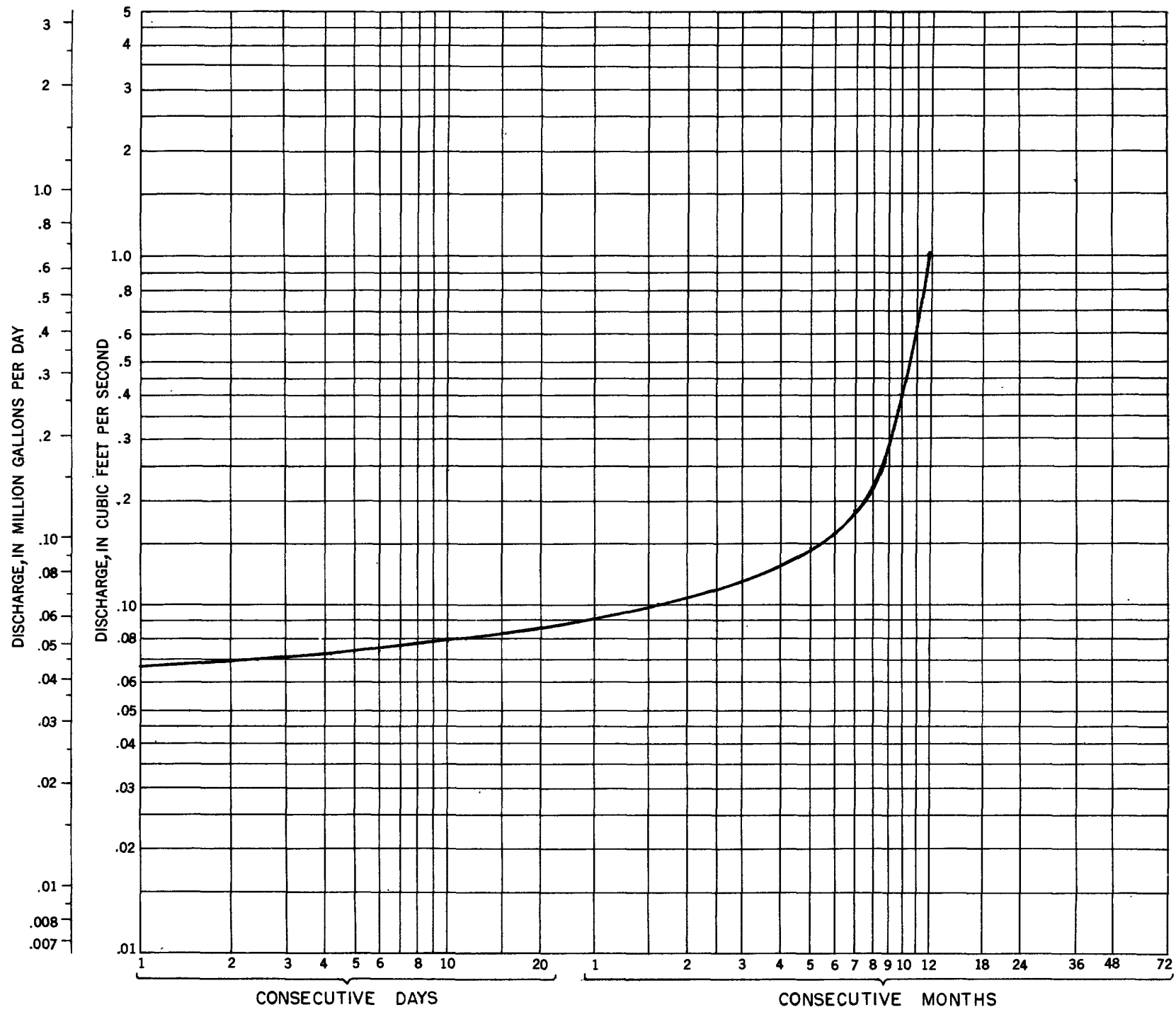

Figure 16. -Maximum period of deficient discharge without storage, Oatka Creek at Garbutt.

Date $\quad \begin{gathered}\text { Gage height } \\ \text { (feet) }\end{gathered} \quad \begin{gathered}\text { Discharge } \\ \text { (cfs) }\end{gathered}$

Apr. 7,1947

Feb. 20, 1948

6.80

5.32

3,680

Mar. 17, 1948

Mar. 23, 1948

Mar. 29, 1950

Apr. 6, 1950

Low flows. - The minimum daily discharge recorded since October 1945 is $10 \mathrm{cfs}$ on Dec. 9, 1949. The flow-duration curve, figure 15 , and the curve showing maximum period of deficient discharge, figure 16, indicate the low-flow characteristics of the stream.

Quality. -Quality and temperature data are not available for this stream.

\section{Irondequoit Creek}

Irondequoit Creek rises in Monroe County about 10 miles southeast of Rochester at an elevation of 600 feet. It flows northward about 15 miles to Irondequoit Bay. The drainage area at its mouth is 152 square miles.

Discharge. -Continuous disčharge records have not been collected on this stream; however, five discharge measurements have been made on the creek since June 1949. These measurements were made just upstream from the barge canal. The drainage area at this point is 55.6 square miles. A flow-duration curve (fig. 17) and a curve of maximum period of deficient discharge (fig. 18) have been estimated by correlating the discharge measurements with records of discharge of Oatka Creek at Garbutt and Black 


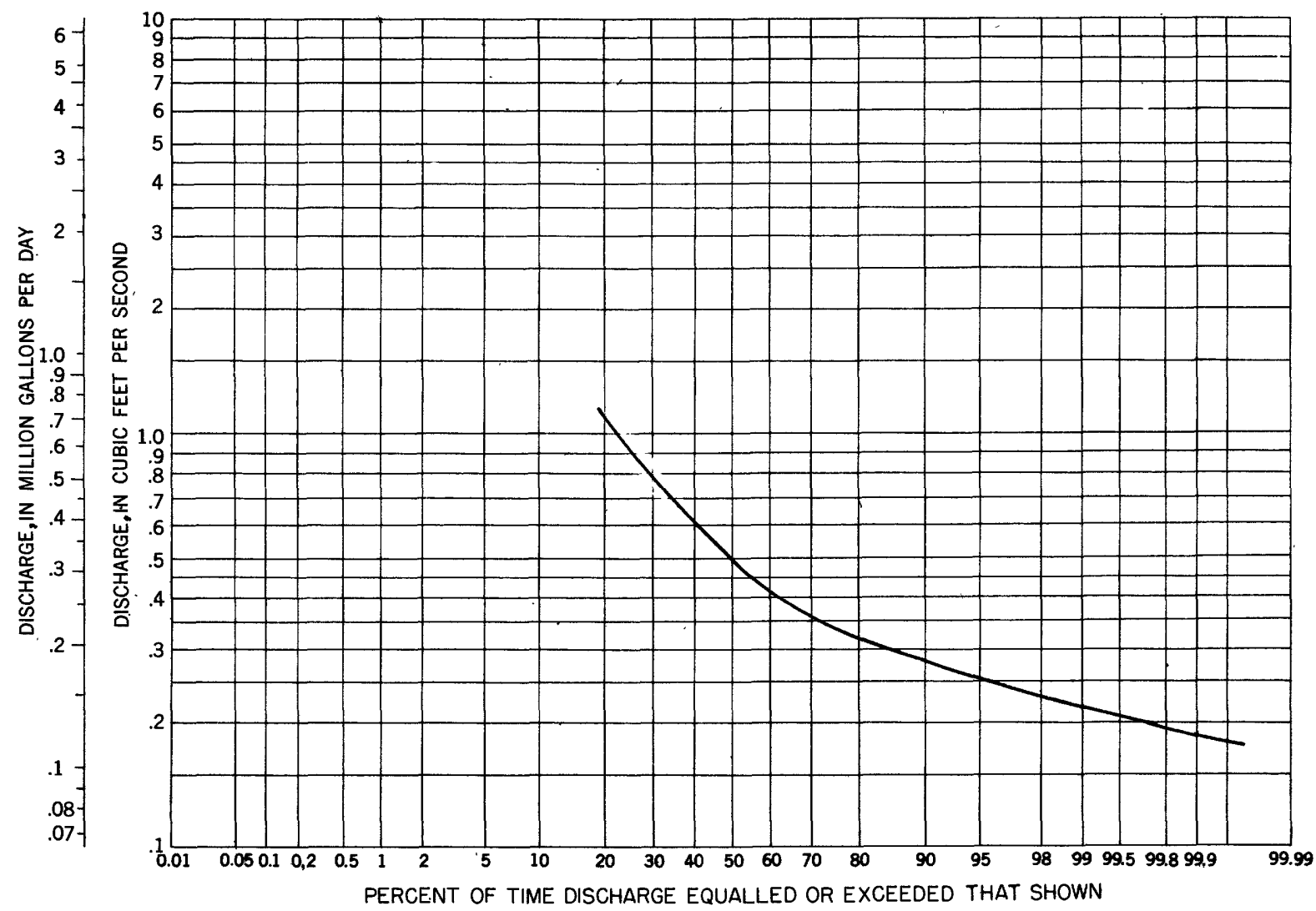

Figure 17. - Estimated flow-duration curve for Irondequoit Creek above barge canal at Bushnell Basin.

Creek near Churchville. These curves show that the stream has very desirable low-flow characteristics. The flow per square mile that is exceeded 99 percent of the time is more than twice that exceeded 99 percent of the time at Garbutt on Oatka Creek and about 10 times that exceeded 99 percent of the time at Churchville on Black Creek. These curves only apply to the stream above the New York State Barge Canal. The flow downstream from the canal may be greater than shown by the curves because the stream sometimes receives overflow from the canal.

Quality. - Information on the chemical quality or temperature of Irondequoit Creek water is not available. The effluent from Rochester's Tryon Park sewage plant, two sewage plants in the town of Brighton, and two sewage plants in the town of Perinton is discharged into Irondequoit Creek or its tributaries. This sewage receives primary treatment at the Tryon Park plant and secondary treatment at the other plants.

\section{Other Streams}

Drainage areas of eight ungaged streams of significance in the area are shown in table 2.
Table 2.-Drainage areas of small streams in the Rochester area

\begin{tabular}{|c|c|}
\hline Streams & $\begin{array}{l}\text { Drainage area } \\
\text { (square miles) }\end{array}$ \\
\hline Fourmile Creek.. & 24.0 \\
\hline Little Black Creek. & 18.0 \\
\hline Round Pond Creek................ & 21.1 \\
\hline Larkin Creek.................................. & 14.5 \\
\hline Northrup Creek............. & 23.5 \\
\hline Buttonwood Creek..................... & 10.3 \\
\hline Salmon Creek............... & 67.1 \\
\hline West Creek.................... & 33.9 \\
\hline
\end{tabular}

These streams all rise between 400 and 650 feet above sea level. Streamflow information is not available for these streams but the drainage areas are small and their yield is probably not large. Suitable water-supply locations on them would probably be near the Lake Ontario level and pumping would be necessary to supply water to the Rochester area.

\section{GROUND WATER}

Ground water occurs in practically all the rocks found in the Rochester area but only a few of these 


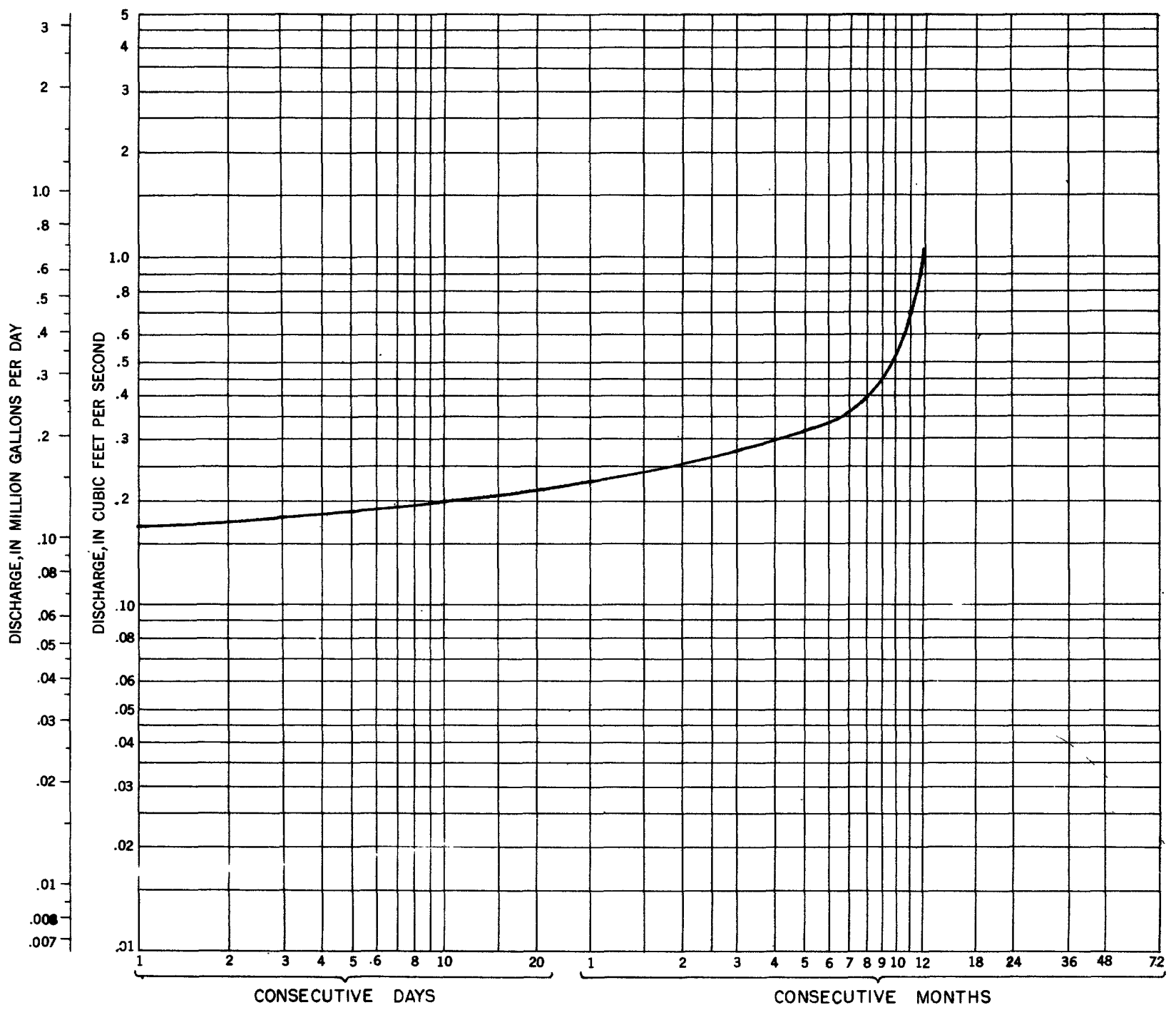

Figure 18.-Estimated maximum period of deficient discharge without storage, Irondequoit Creek above barge canal at Bushnell Basin. 
are important sources of acceptable water. Where there are good waterbearing formations, ground water may provide a more economical source of supply for industries and private consumers than surface water. Ground water is available in many places remote from streams or lakes, or from public supplies. It is also comparatively free from bacteria and suspended matter and is relatively uniform in chemical composition, although locally ground water has a higher average mineral content than surface water. The more uniform temperature of ground water, which in the summer is lower than that of surface water, may make it especially desirable for cooling purposes.

The availability of ground water is dependent not only on precipitation but also on the character and structure of the geologic formations. The velocity of ground-water movement depends on the ability of a formation to transmit water (permeability) and on the difference in pressure (head) causing the movement. In the Rochester area, as elsewhere, permeability is dependent upon the number, size, shape, and arrangement of the subsurface openings. These openings are generally of two kinds. In the unconsolidated materials, water occurs in the spaces between individual grains or particles. In the bedrock, water commonly occurs in secondary openings developed by solution or fractures but may occur in sandstones in which the openings between grain have not been filled with cementing material.

\section{Waterbearing Formations}

The bedrock in the area consists chiefly of dolomite, shale, and sandstone. These were originally laid down as sea-bottom sediments during the Silurian and Ordovician periods about 360 to 400 million years ago. The consolidated sedimentary rocks now strike approximately east-west and dip 40 to 60 feet per mile toward the south. Because the beds dip to the south and the land surface rises in that direction, any given formation lies farther and farther below the surface southward, as shown in the cross section on plate 2. Consequently the younger rocks are exposed in the southern part of the county and the older, underlying rocks are exposed along the shore of Lake Ontario. Overlying most of the bedrock are unconsolidated deposits consisting largely of bedrock debris broken up and carried southward by glacial ice. Some of this glacial material has been sorted by stream action so that in some places clean sand and gravel is abundant. The thickest glacial deposits lie in a buried valley named Irondogenesee (Fairchild, 1935). Fairchild's theory that the valley was first cut by the preglacial Genesee River and later filled by the advancing ice has been confirmed by subsequent drilling.

Plate 1 is a map of the bedrock topography. The Fairport-Lyons channel, which heads eastward through Wayne County, is believed to have been the outlet for glacial Lake Dawson, which occupied the Genesee Valley near Rochester during the Ice Age.
This channel and the larger Irondogenesee buried valley have been identified by plotting bedrock altitudes obtained from many well records. A seismic study made in the southern part of the mapped area indicates that some modification of the mapping of local areas may be necessary. In the Rush area, thick deposits of unconsolidated material were discovered more than 1 mile north at the Irondogenesee channel as shown on plate 1 . However, the principal features are believed to be essentially as shown.

The bedrock map can be used to estimate the thickness of the unconsolidated material if the altitude of a proposed well site is known. Thus, if the surface altitude is 400 feet and the bedrock altitude about 250 feet, the difference between the two, or 150 feet, is the approximate thickness of glacial material at the site. The inset on plate 1 shows the name of all the U. S. Geological Survey topographic maps which show altitude in the area.

\section{Water-Level Fluctuations}

The water levels in most wells in the area lie on an irregular surface below which the ground is saturated with water. The upper surface of this zone of saturation, known as the water table, fluctuates annually and sometimes daily in response to changing conditions. Withdrawals from storage result in a lowering of the water table if combined losses are not balanced by replenishment from precipitation or surface-water sources. In the Rochester area, the water table generally lies farthest below the surface in high hilly areas, as in the southeast, and nearest to the surface in the valleys and the lowlands. The water table slopes toward the surface streams, the Irondogenesee buried valley, and toward the Lake Ontario lowland in the north. The down gradient movement of subsurface water to these and other low areas is usually unconfined. In some wells, however, particularly in the abandoned Irondogenesee valley, the water may rise to a height above that in which it occurs in the formation owing to impermeable layers capping the aquifer locally. More rarely, the hydrostatic pressure is enough to cause the water to flow at the surface. Fewer than 50 flowing artesian wells have been recorded in the thousands of wells listed in Monroe County. Fluctuations of water level in observation wells in the Rochester area are shown in figure 19. Springs and seeps occur in areas where a steeply sloping land surface intersects the water table. More than 100 springs have been recorded in Monroe County of which about 70 are in the Rochester area. Springs have not been included in this report because their low average yield and other unfavorable characteristics generally make them unsuitable for most industrial purposes.

\section{Yield of Wells}

Most of the consolidated rocks of the Rochester area yield small supplies of water. Excluding the Lockport 

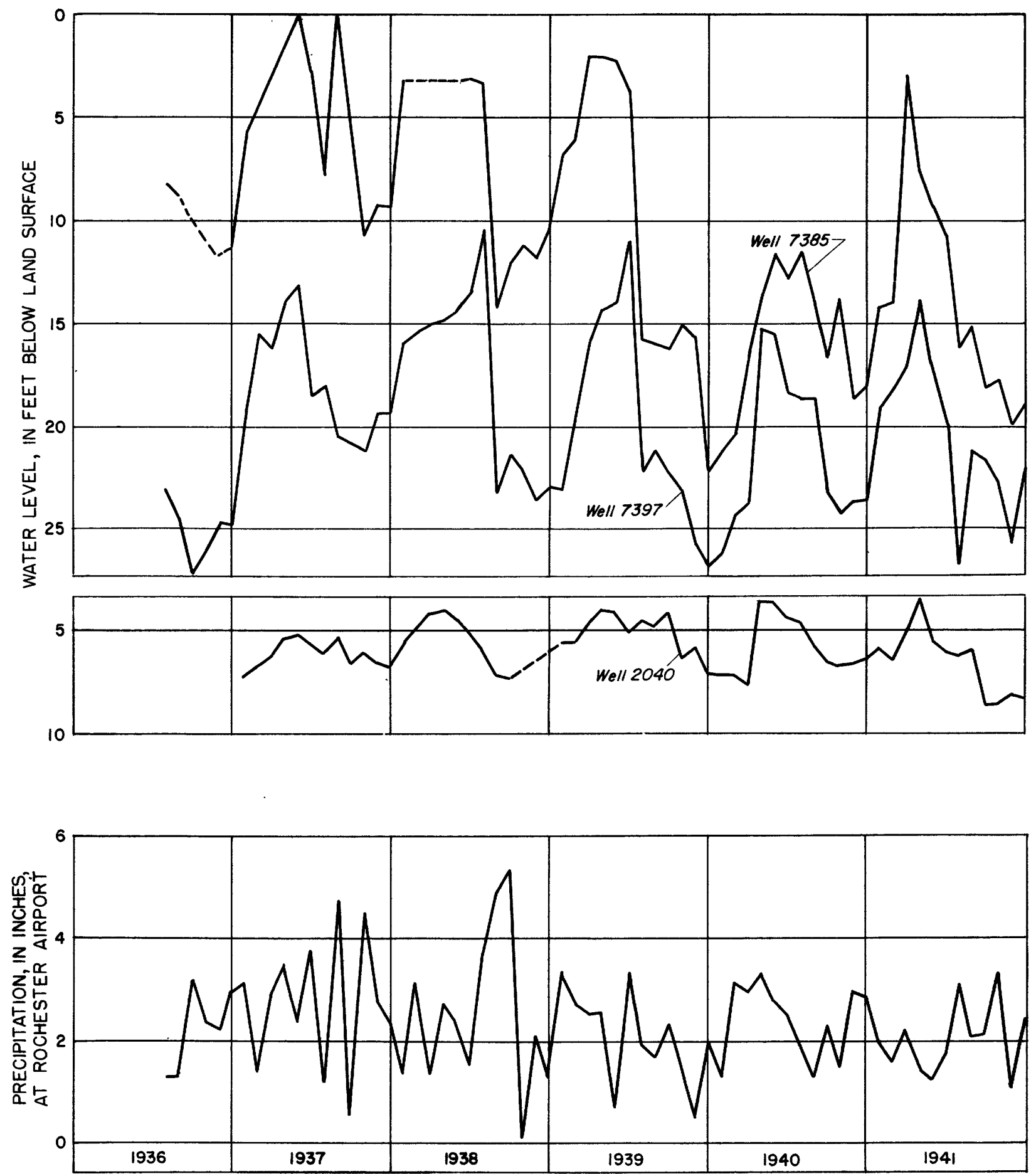

Figure 19. -Water levels in observation wells 7385, 7397, and 2040 and monthly precipitation at Scottsville, July 1936 to December 1941. 
Table 3.-Waterbearing properties of unconsolidated and bedrock aquifers in the Rochester area

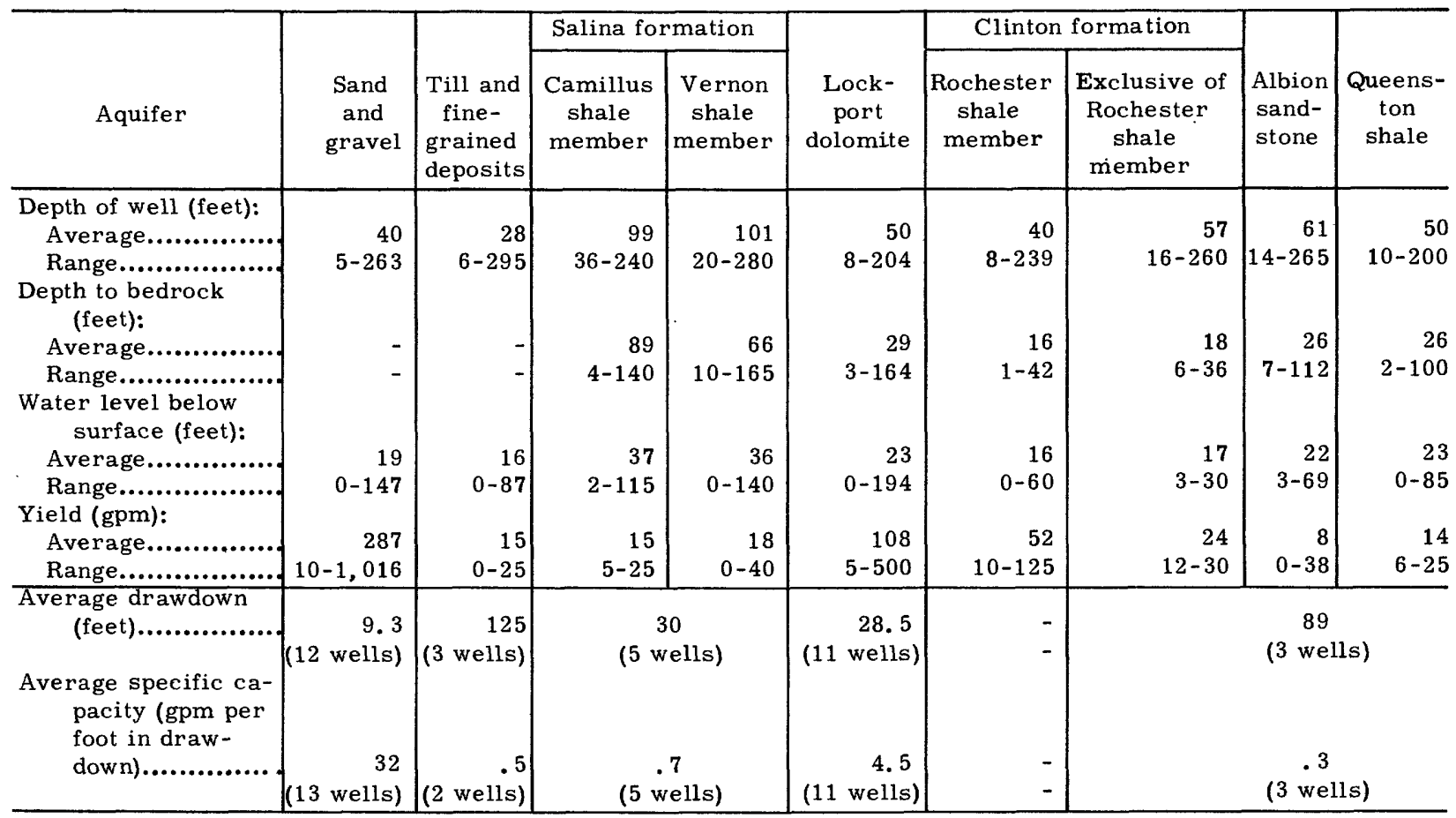

dolomite, the average yield of 37 bedrock wells is less than $\mathbf{4 0}$ gpm (gallons per minute) with a maximum reported yield of $125 \mathrm{gpm}$. The Lockport dolomite is the most productive bedrock aquifer in the area. Yields from 21 wells in the Lockport average $108 \mathrm{gpm}$ and range from 5 to $500 \mathrm{gpm}$. The formation contains numerous openings along joints, solution cavities, and bedding planes favorable for the occurrence of ground water. Some of the other formations also contain solution openings. In the Camillus shale, the shaley layers are rather impermeable, but the interbedded gypsum has been wholly or partly leached out in many places and the resultant cavities contain some ground water. Those bedrock formations which owe their porosity and permeability to intergranular openings do not as a rule yield large supplies except where sandy layers may be present, as at the top of the Rochester shale. Table 3 gives average yield and range in yield for wells in each of the waterbearing formations in the area. The areal distribution of the bedrock waterbearing formation is shown on plate 2 .

Highly permeable sand and gravel partly fill the abandoned valley of the preglacial Genesee River, Irondogenesee buried valley. These sediments generally provide a much more dependable and larger yield than is common for the bedrock formations in the area. The reported yield of 23 wells in the Pleis tocene sand and gravel average $287 \mathrm{gpm}$ and range from 10 to $1,016 \mathrm{gpm}$. Table 3 shows the averages and extremes of water levels and yields from both the bedrock and the unconsolidated deposits.

\section{Drawdown and Specific Capacity}

Where relatively large amounts of water are required, it is frequently necessary to drill two or more wells to obtain an adequate supply. In such places, a knowledge of the closest possible spacing consistent with optimum yield may be necessary. The radius of influence, or maximum horizontal distance to which a pumped well lowers the water table, is best determined by measurements made on adjacent observation wells while pumping is in progress. A test made for the New York Water Service Corporation at Penfield in May 1950 showed that the radius of influence exceeded 900 feet at permanent well No. 1 (U. S. Geol. Survey well Mr 15309) tapping the sand and gravel aquifer. The water level in an observation well, 908 feet from the supply well, declined about an inch within approximately 1 hour after pumping began at the rate of $1,000 \mathrm{gpm}$. Further decline in water level in the observation well was small, amounting to less than 3 inches in 6 hours of intermittent pumping. This test indicates that to achieve minimum interference among wells having the stated performance, the distance between wells should be at least 1,800 feet. In many instances economic considerations result in closer spacing of wells than is indicated by such tests. The performance of an aquifer also may be determined by measurements of water levels in observation wells, rate and duration of discharge, and distances of observation wells from the pumping well. The term coefficient of transmissibility is used in such tests to define the rate of flow of water in gallons per day through a vertical strip of the aquifer 1 foot wide and extending the full saturated height under a hydraulic gradient of 100 percent. A preliminary aquifer-performance test on the two Webster wells by C. E. Jacob in 1940 showed that the coefficient of transmissibility of the sand and gravel was about 45,000 gpd per foot. 


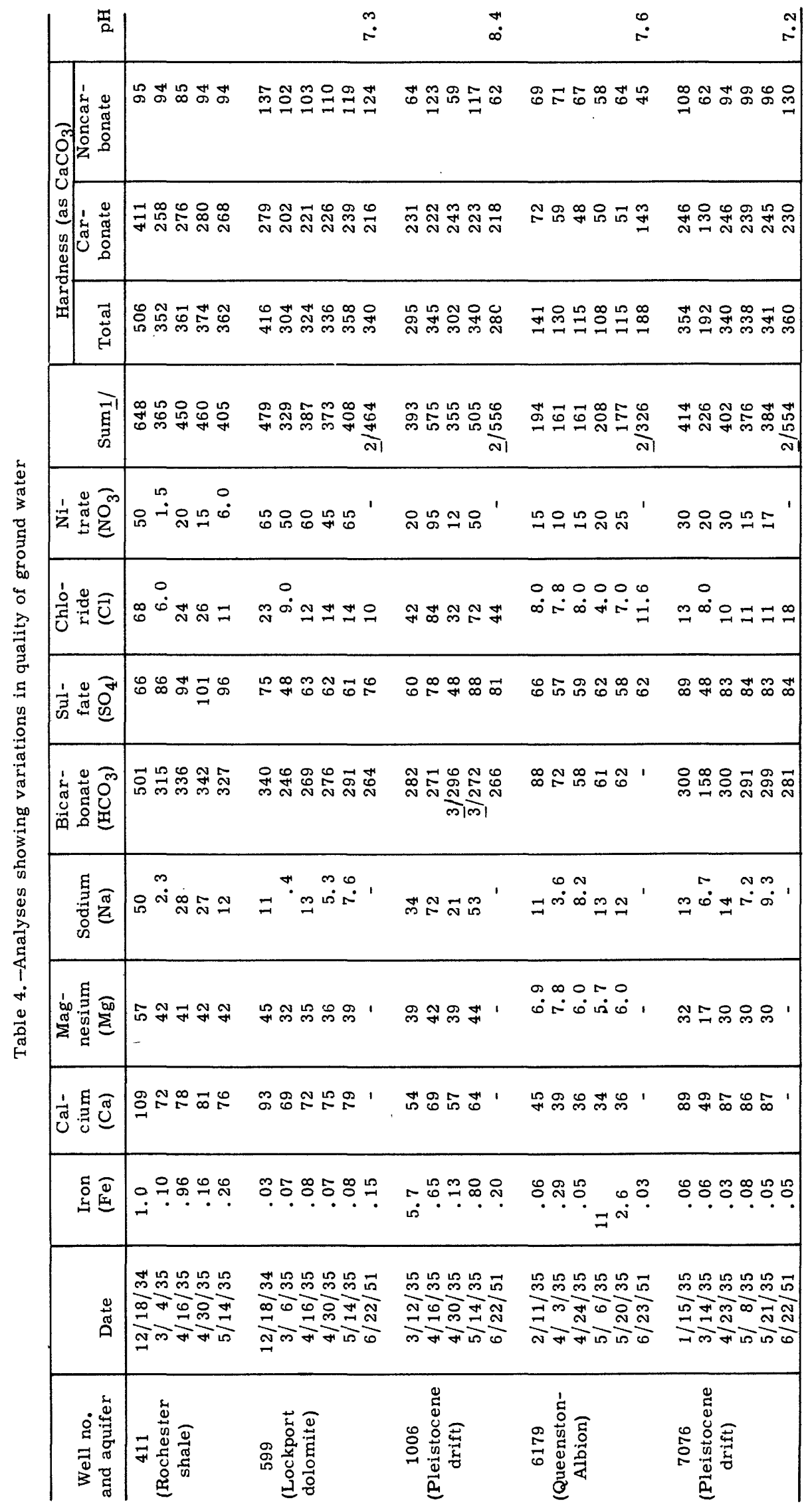


Table 5. -Chemical quality of ground water in the Rochester areal

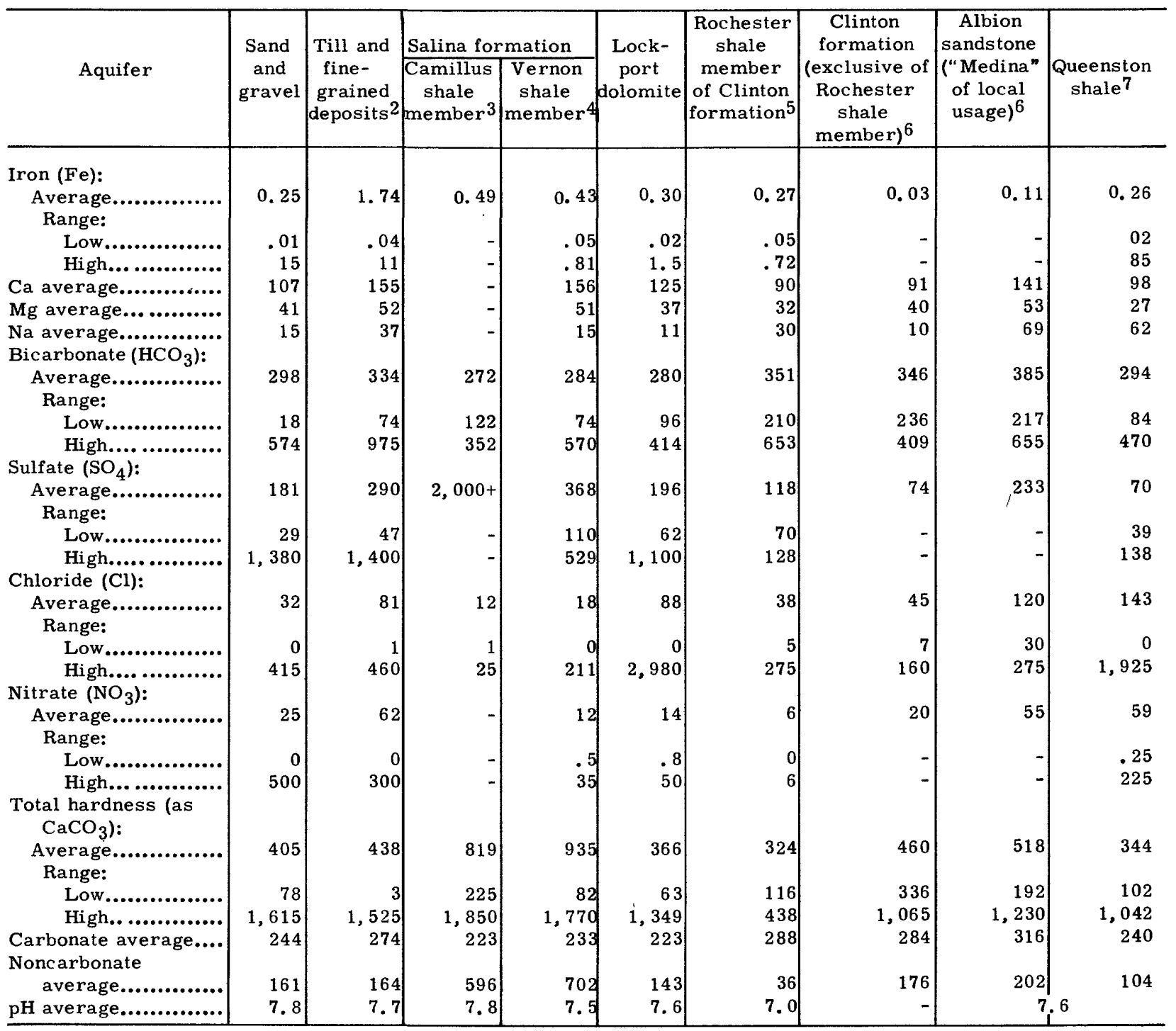

1 Averages for iron, calcium, magnesium, sodium, sulfate and nitrate based on total of 65 analyses; averages for bicarbonate, chloride and hardness based on 610 analyses.

2 Includes clay, drift, silt, till, hardpan, quicksand, and muck.

$3 \mathrm{Fe}$ sulfate and $\mathrm{pH}$ based on only one sample. Sulfate determination approximate.

$4 \mathrm{pH}$ based on only one sample.

$5 \mathrm{NO}_{3}$ and $\mathrm{pH}$ based on only two samples.

$6 \mathrm{Fe}, \mathrm{Ca}, \mathrm{Mg}, \mathrm{Na}, \mathrm{SO}_{4}$ and $\mathrm{NO}_{3}$ based on only one sample.

$7 \mathrm{pH}$ based on only one sample.

In the absence of aquifer performance tests, inferences may be made from the drawdown, or difference between pumping level and nonpumping level in a well. Drawdown data are also necessary in order to determine the dependability of performance and for the estimation of pumping costs. The average drawdown in 19 bedrock wells with a mean yield of $12 \mathrm{gpm}$ is 38 feet. Drawdown is commonly expressed as specific capacity, or yield in gallons per minute per foot of drawdown. Thus, the specific capacity of these bedrock wells is only $3.2 \mathrm{gpm}$ per foot (table 3 ). By contrast, the mean drawdown in 12 sand or gravel wells yielding an average of $300 \mathrm{gpm}$ is only about 9 feet and the specific capacity is 32 gpm per foot drawdown. Table 3 shows average and extreme pumping levels, drawdowns, and specific capacities of the 34 wells for which such information is available.

\section{Quality of Ground Water}

The amount of information available permits an accurate appraisal of the chemical quality of ground waters within the area. In 1934, samples from 1,312 wells and springs were collected in Monroe County. These samples were analyzed for bicarbonate, chlo- 
ride, and total hardness. Of these wells and springs, 179 were selected for more complete analysis of which 24 were given four check analyses at intervals of 2 weeks. Eight of the 24 repeatedly checked wells are in the Rochester area; 4 of the 8 wells were resampled in 1951 to determine whether any long-term changes could be detected. Table 4 shows the result of all the repeated analyses in the area. The chief reason for repeating the analyses was the considerable differences in the quantities of some of the constituents in the partial and complete analyses. These wells represent the more extreme variations likely to be found in individual wells and repeated analyses of other wells may be expected to exhibit more of the relative uniformity of . chemical constituents which distinguishes ground water from surface water. Some apparent variations in the quality of water as shown in table 4 are probably attributable to differences in sampling methods and laboratory techniques as well as to hydrologic factors. Approximately 25 additional analyses were furnished by commercial sources and by the Rochester office of the New York State Department of Health. The results of more than 610 analyses of water from the Rochester area are summarized in table 5 . In evaluating the reliability of these analyses, it should be noted that the averages for bicarbonate, chloride, total hardness, carbonate hardness and noncarbonate hardness are based on about 610 analyses, whereas the averages for iron, calcium, magnesium, sodium, sulfate, and nitrate are based on only about 65 analyses.

Ground water in the area is generally hard. The average total hardness for all bedrock aquifers is $\mathbf{5 0 0}$ ppm. The lowest average hardness is in water from the Rochester shale (324 ppm) and the highest, in water from the Vernon shale $(935 \mathrm{ppm})$. Water from sand and gravel deposits averages only slightly softer (420 ppm) than bedrock water and shows a wider range in hardness (78-1,615 ppm) than water from any individual bedrock formation with the exception of the Vernon shale. The Rochester shale shows the smallest range in hardness (116-438 ppm).

Total hardness consists of carbonate (or temporary) hardness and noncarbonate (or permanent) hardness. The noncarbonate type is more difficult, and hence more expensive, to remove. Noncarbonate hardness makes up 50 percent of the average total hardness in water derived from local bedrock and $\mathbf{4 0}$ percent of the average total hardness in water obtained from sand and gravel in the area.

Other undesirable chemical constituents are present in waters from some sources. Table 5 shows that the average iron content of water from Vernon and Camillus members of the Salina formation exceeds the maximum of $0.3 \mathrm{ppm}$ recommended by the U. S. Public Health Service. Manganese, which should be totaled with iron to determine the maximum, has not been determined in most cases. On the other hand, the averages for magnesium are generally well below the recommended limit of 125 ppm in water from both consolidated and unconsolidated aquifers. The average chloride content is likewise well below the permissible limit of $250 \mathrm{ppm}$. The same is generally true for sulfates although the Vernon shale (averages $368 \mathrm{ppm}$ ) and the Pleistocene deposits other than sand and gravel $(290 \mathrm{ppm})$ exceed the permissible sulfate limit of 250 ppm. The meager data available on $\mathrm{pH}$ suggest that ground water in the area is generally neutral to moderately alkaline. The pH of 30 samples ranges from 6.7 to 8.4 .

Slight fluctuations in water quality are caused by changes in recharge. Table 4 shows that most of the repeatedly analyzed water is softest in the early spring when recharge is greatest and that hardness and dissolved solids may increase slightly in the winter.

Hardness and dissolved solids in water from the bedrock of the Rochester area commonly increase with depth. There is no unanimity as to the change in mineralization with depth in the unconsolidated deposits such as those in the Irondogenesee valley. It is believed that the underlying bedrock influences the chemical quality of water from the unconsolidated deposits, at least in some places. For example, hydrogen sulfide was reported from one of two permanent wells (U. S. Gęological Survey well Mr 15309) drilled for the New York Water Service Corporation in a part of the buried valley underlain by the Lockport dolomite. After aeration had been attempted, the hydrogen sulfide was successfully removed by chlorination. However, in an effort to avoid chlorination costs, the bottom 18 inches of the well, believed to be the source of the hydrogen sulfide, was sealed off, and the well subsequently produced water of satisfactory quality for a public supply. Griswold (1951) reports that much of the water from the Lockport dolomite in adjacent Wayne County contains hydrogen sulfide, probably due to the presence of sphalerite (zinc sulfide). Twelve of 16 sulfurous bedrock wells in the Rochester area inventoried in 1951 obtained water from this formation.

Mineralized ground water that is undesirable for some specialized purposes may be used for cooling where temperature, rather than quality of water, is of prime importance. Where-the principal requirements are for a cool (and uniform-temperatured) noncorrosive water with a turbidity less than $50 \mathrm{ppm}$, ground water may be the most economical agent. The abandonment of a few prolific wells drilled for use in cooling, coupled with the high averages for hardness and dissolved solids indicates that locally the desirable temperature characteristics may be more than offset by high mineralization.

\section{Pollution}

Ground water in the area generally is less subject to pollution than surface water, not only because it receives natural filtration but also because industrial and municipal wastes are commonly discharged into surface streams. In a few places, however, the danger of subsurface contamination has been increased by the drilling of drainage wells for underground discharge of wastes. Three such wells were noted during a survey in 1934. Only two were recorded in the present survey and it is believed that the total number is small. Some drainage wells have already been abandoned because natural filling up renders them useless.

Water from the Lockport dolomite and other formations containing secondary openings may sometimes be less free of pollution than that from bedrock aquifers dependent on primary porosity because water 
Table 6.-Temperature of ground water in the Rochester area

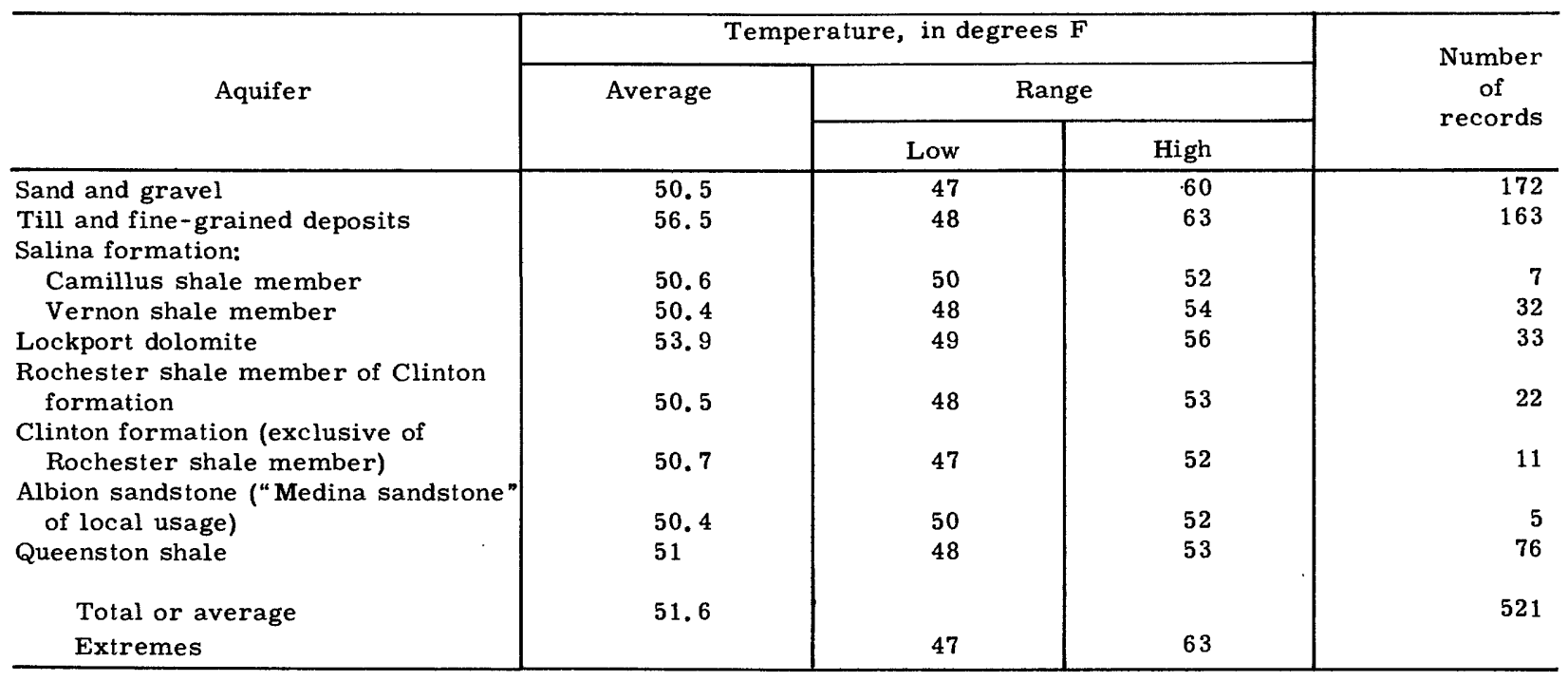

moving through large solution channels does not undergo natural filtration. Pollution in one well in Monroe County drilled into the Lockport dolomite was reportedly traced to a source three-tenths of a mile away.

\section{Temperature}

The temperature of ground water generally remains within a few degrees of the mean annual air temperature throughout the year. Measurements of groundwater temperatures in approximately 600 wells of all types in the area average $51.5^{\circ} \mathrm{F}$ and range from $46^{\circ}$ to $64^{\circ} \mathrm{F}$. Temperatures in shallow bedrock wells (those less than 60 feet deep) do not differ much from deeper bedrock wells (maximum depth 295 feet). Water from shallow dug wells in unconsolidated deposits which are mixed or clayey shows a higher average temperature $\left(56.5^{\circ} \mathrm{F}\right)$ and a wider range $\left(15^{\circ} \mathrm{F}\right)$. Unconsolidated sand and gravel yields water with a wider range in temperature $\left(13^{\circ} \mathrm{F}\right)$ than rock water, although averaging about the same. Because the Lockport dolomite contains large solution cavities in which the movement - of ground water somewhat resembles surface conditions, water temperatures vary more widely $\left(49^{\circ}\right.$ to $\left.56^{\circ} \mathrm{F}\right)$ and average slightly higher $\left(53.9^{\circ} \mathrm{F}\right)$ than those in other bedrock aquifers. Table 6 shows mean temperatures and ranges in all the local aquifers.

\section{PUBLIC WATER-SUPPLY SYSTEMS}

\section{$\underline{\text { Rochester }}$}

The Rochester municipal water system is composed of the domestic system and the Holly system. The domestic system is composed of the Upland system, supplied from Canadice and Hemlock Lakes and the Lake Ontario development. The maximum capacity of the lines from the Upland system to the city reservoirs is about $49 \mathrm{mgd}$. The Holly system, which is for fire protection only, supplies about $\frac{1}{2} \mathrm{mgd}$. The Lake Ontario development will supply $60 \mathrm{mgd}$ when completed. Canadice and Hemlock Lakes, the twin sources of supply for the Upland system are about 30 miles south of the city. Water flows from Canadice Lake to Hemlock through a 5-foot concrete conduit. Hemlock Lake is about 380 feet above the general level of Rochester and delivers water to the city, by gravity, through three conduits. The total drainage area of this supply source is about 66 square miles. The maximum storage capacity of Canadice and Hemlock Lakes is estimated to be 1,500 million cubic feet or 11,220 million gallons.

Three reservoirs connect with the Rochester Upland system: one, about 9 miles south of the center of the city, has a capacity of $63 \frac{1}{2}$ million gallons; another, on the southern border of the city, has a capacity of $22 \frac{1}{2}$ million gallons; the third, at the southeastern border of the city, has a capacity of 144 million gallons. Thus the total reservoir storage is about 230 million gallons or less than 5 days' supply, assuming a demand of 60 mgd. The southernmost reservoir is about 220 feet above the general altitude of the city while the last two are about 110 feet higher than the city. The municipal distribution system serves all of the city except portions of five wards which are served by the Rochester and Lake Ontario Water Service Corp.

Chlorination is the only treatment of the Upland supply. An analysis of the water is given in table 1.

The Lake Ontario development is under construction. Water will be obtained from Lake Ontario through an intake owned by the Eastman Kodak Co. The plant will be municipally owned and ready for use late in 1953.

At present (1952) the city of Rochester augments the supply by purchases of as much as $4 \mathrm{mgd}$ from the Eastman Kodak Co. During 1950, the city purchased an average of $1.5 \mathrm{mgd}$ from Eastman Kodak Co. 
The Holly system is a separate system of mains operated to supply hydrants and automatic sprinkler systems in the business area and parts of the manufacturing district. Water is obtained from the domestic system but in times of extreme emergency water can be taken from the Genesee River. Consumption averages 300,000 gpd (gallons per day) but records are incomplete as meters do not record consumption when fire pumps are operated.

Recent tests conducted by the National Board of Fire Underwriters show that this system has deteriorated to a point where it cannot be depended on to provide more than a primary supply for automatic sprinklers.

\section{Rochester and Lake Ontario Water Service Corp.}

This corporation, a division of the New York Water Service Corp., supplies water to several towns and villages surrounding Rochester, and to several wards in Rochester. Present consumption averages about 14 mgd and during the summer months has averaged 16 $\mathrm{mgd}$, with a maximum demand of $20 \mathrm{mgd}$. For peak demands the corporation obtains water from the c1ty of Rochester. The pumping station and filtration plant are just outside the northwestern limits of Rochester, as shown in plate 1. A 24-inch intake extends 3,900 feet into Lake Ontario with the crib under 23 feet of water. In 1944 a 36 -inch intake, 2, 500 feet long, with a separate crib, was joined to the 24 -inch intake at a point 1,400 feet offshore. The present intake has a rated capacity of $18 \mathrm{mgd}$, and the pumping station is rated at $33 \mathrm{mgd}$. The filtration plant is rated at 11 mgd. Treatment consists of chlorination, coagulation, pressures and filtration, and the use of carbon. Storage available totals 8.5 million gallons. All services are metered.

\section{East Rochester}

The village of East Rochester developed its own supply in 1935 from two wells drilled to a depth of about 170 feet. The wells are 1,000 feet south of the village, and tap the productive sands and gravels of the Irondogenesee Valley. Each well yields about $700 \mathrm{gpm}$ (gallons per minute). The water is raised by two deepwell turbine pumps to a 500,000 gallon standpipe located within the village limits. Consumption is 250,000 to $300,000 \mathrm{gpd}$ and storage capacity is 500,000 gallons. A zeolite softener treats one-half of the water. An equal volume of untreated water is bypassed around the softener and later mixed with the softened water so that the final product delivered to the public has a hardness of about $132 \mathrm{ppm}$. Although the untreated water has a total hardness of about 256 ppm, it is of satisfactory quality in other respects.

\section{Scottsville}

Scottsville obtains its water from an infiltration gallery beside Oatka Creek near Ice Pond. After chlorination, water is pumped to an elevated tank having a capacity of 50,000 gallons. Total storage capacity is 115,000 gallons. Pumping equipment has a capacity of $150 \mathrm{gpm}$. Prior to 1936, water was obtained directly from the creek and filtered, through slow sand filters having a capacity of $200,000 \mathrm{gpd}$. After construction of the infiltration gallery in 1936 filtration was discontinued and chlorination used. Maximum daily consumption exceeded 38,000 gallons in 1951 . The water is very hard, $840 \mathrm{ppm}$, most of which is noncarbonate (permanent) hardness (New York State Department of Health, 1948).

\section{Webster}

The consumption of water at Webster increased from a daily average of less than 200,000 gallons in 1946 to almost 300,000 in 1951. Consumption in neighboring water districts served by the same system increased from about 77,000 to more than $130,000 \mathrm{gpd}$ in the same period. Water is obtained from two wells each about 400 feet deep, located near the shore of Irondequoit Bay. The water is raised from the sands and gravels of the buried valley by pumps having a capacity of $360 \mathrm{gpm}$. It is then pumped to a concrete storage reservoir and 2 storage tanks. Total storage capacity is $1,662,000$ gallons. No treatment is needed. Most of the total hardness, which is about $158 \mathrm{ppm}$ is of the noncarbonate type. To take care of expanding demands, a third well was drilled in 1951 and when tested was found satisfactory.

\section{Pittsford}

The village of Pittsford, which purchases its water from the New York Water Service Corp., had 10 test wells drilled in 1949 and 1950 to determine whether a satisfactory supply could be obtained from the unconsolidated deposits successfully serving Webster and East Rochester. A few wells yielded only 10 to 15 gpm but two reportedly yielded $325 \mathrm{gpm}$. Permanent wells were drilled but had not been put into use by late 1952.

\section{PRESENT WATER USE}

The heavy industrialization of the Rochester area has increased the demand for water from all sources. The local manufacture of only 1 ton of a representative type of paper requires about 18,000 gallons of water. The doubling of the population since 1900 has also made heavy demands on municipal water supplies. Total consumption of water from all sources exceeds $192 \mathrm{mgd}$. Surface-water utilization alone totals more than $188 \mathrm{mgd}$. This includes $75 \mathrm{mgd}$ used by the Rochester Gas and Electric Co. for steam plants generating electric power. Only about 2 percent (3. 72 mgd) is obtained from subsurface sources. Water use in the area is primarily nonconsumptive; most of it is soon returned to the Genesee River and Lake Ontario, where it is available for further use. Ground water is not generally returned to an aquifer.

\section{Use by Public Supplies}

Public water supplies in the Rochester area require an average of about $63 \mathrm{mgd}$ of which about $62 \mathrm{mgd}$ is from surface sources (see table 7). 
Table 7.-Use of water for public supplies

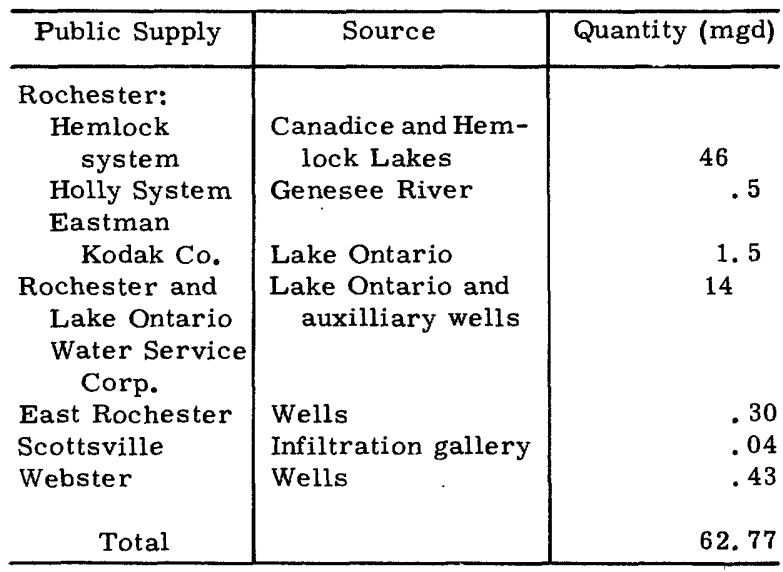

\section{Industrial Use}

A survey of about 470 industries in the area discloses that comparatively few obtain their water from private supplies. About 405 industries, or 86 percent, purchase water from the city of Rochester. Approximately 34 , or 7 percent, have a combined supply from both the city and the Rochester and Lake Ontario Water Service Corp. A few in this group obtain water from only one of these sources but the exact source was not determined. About 17 users, or 3.5 percent, purchase water from surrounding municipalities such as East Rochester, Fairport, Pittsford, and Webster. The remaining 3.5 percent depend principally on their privately owned supplies. Most of the privately owned supplies utilize ground-water sources, the chief exceptions being the Eastman Kodak Co., and the Rochester Gas and Electric Co. The Rochester Gas and Electric Co. uses $75 \mathrm{mgd}$ from Lake Ontario at their steam-electric generating plant.

Eastman Kodak Company. -The Eastman Kodak Co. has its own water and pumping and treatment plant for processing and cooling purposes. Twin intakes extend about $1 \frac{1}{2}$ miles into Lake Ontario and have a combined capacity of $100 \mathrm{mgd}$. The pumping station is $21 / 4$ miles northwest of the Genesee River at Round Pond (see pl. 1). It has a capacity of $33 \mathrm{mgd}$. The filtration plant is also rated at $33 \mathrm{mgd}$. Consumption ranges between 25 and $28 \mathrm{mgd}$.

One sample of untreated water and one of treated water from this system were collected and analyzed during the summer of 1951 . The analyses are given in table 1 .

Water power. - The Rochester Gas and Electric Co. has four hydroelectric plants on the Genesee River within the city. These plants develop power from the entire flow on the river when it is less than about $5,000 \mathrm{cfs}$ and usually operate at full load at higher discharges in the river. A net flow of about $600 \mathrm{cfs}$ is diverted from the New York State Barge Canal into the Genesee River for power use during the navigation season of the barge canal.

\section{WATER LAWS}

The development and use of water resources in New York State are under the supervision of the New York State Conservation Department and the New York State Department of Health.

The New York State Water Power and Control Commission of the Conservation Department, the New York State Department of Public Works, and the Department of Law have jurisdiction over the construction of dams and certain other works which may change the regimen of a watercourse. The Water Power and Control Commission is empowered to allocate surface waters for public supply and requires submission of reports, surveys, and designs for public supplies.

The New York State Department of Health, together with other State agencies, is responsible for maintaining surface waters so that they are not injurious to public health. Waste-disposal systems must meet the department's requirements and plans for such systems must be submitted prior to construction. Potable water-supply sources must meet the sanitary requirements of the Department of Health which maintains a local office in the city of Rochester. The Water Pollution Control Board of the Department of Health is in the process of assigning water-quality standards to all waters of New York State. Discharged waste must not pollute the receiving waters beyond the classification standards assigned by the board.

The Corps of Engineers, U. S. Army, has jurisdiction over navigable waterways. A permit for any project involving Lake Ontario, or any other navigable watercourse except the New York State Barge Canal, must be obtained from the Corps of Engineers. The New York State Department of Public Works has jurisdiction over the barge canal.

Local governmental agencies or municipalities in some instances have laws relating to the use of water resources under their jurisdiction. Thus, the city of Rochester has by ordinance restricted the use of water in air-conditioning and refrigeration equipment. The Monroe County Water Authority began functioning in 1951. It is planned to centralize public water supplies by purchasing the local facilities of the New York Water Service Corp.

Upstate New York has no laws relating to the development of ground-water supplies for private or industrial use. However, the practice of discharging polluted or contaminated wastes underground is discouraged.

\section{POTENTIALITIES}

The Rochester area can supply large quantities of additional water for a variety of industrial and other uses. Communities and industries near Lake Ontario have available vast amounts of water of good quality. Although lake water can be obtained directly, most new industries probably will continue to purchase water from the public utilities, thus avoiding additional 
capital investments, legal considerations, and other problems related to lake intakes. Smaller quantities of water having less desirable quality are available from the streams in the area.

The Genesee River is the largest stream in the area. The lowest daily flow between December 1919 and September 1950 was $219 \mathrm{cfs}$ (142 mgd). Black Creek at Churchville may be expected to have a flow of $2 \mathrm{mgd}$ or more for 98 percent of the time. The flow of Oatka Creek at Garbutt may be expected to be $12 \mathrm{mgd}$ or more for 98 percent of the time. Irondequoit Creek has the highest dry-weather flow per square mile of any stream in the area. The flowof Irondequoit Creek. above the New York State Barge Canal (drainage area 55.6 square miles) is $0.15 \mathrm{mgd}$ or more per square mile (about $8 \mathrm{mgd}$ or more at the canal) for 98 percent of the time.

A few aquifers can provide moderate to large supplies of water with uniform temperature and relatively free from turbidity or pollution but of ten with high mineral content. Waters of high mineral content, particularly of bedrock water, are limited to such specialized uses as cooling and air-conditioning. For most municipal or industrial uses, it is necessary to install treatment plants or dilute with less-mineralized surface water. The bedrock formations probably cannot supply large amounts of water for industrial or commercial use. The chief exception is the Lockport dolomite which yields an average of $108 \mathrm{gpm}$ but the yields are quite spotty, ranging from less than 5 to as much as $500 \mathrm{gpm}$. The yield of a well producing from the Lockport dolomite cannot be predicted because the yield depends on chance intersection with solution cavities.

The Rochester shale is another aquifer that has some possibility of yielding sufficient water for industrial use. The average depth of all wells recorded in the shale is only 40 feet, the shallowest for bedrock in the area. The average yield of $52 \mathrm{gpm}$ is second to the Lockport dolomite in bedrock productivity. Although drawdown or specific capacity data for wells in the Rochester shale are not available, availability of water from the formation merits further investigation for some uses because its waters have the lowest average hardness (324 ppm) and the smallest range in hardness (116-438 ppm) for bedrock waters.

The relatively low yields in the Vernon and Camillus shale members of the Salina formation are somewhat surprising in view of the productivity of the Salina formation in adjacent Wayne County to the east and in the Buffalo area to the west. The chemical quality of Salina water is poor in all three areas. In general, the low yields and poor quality of water from most of the bedrock aquifers other than the Lockport usually discourages drilling for industrial use in the Rochester area. Less than 5 percent of the leading industries in the area obtain water from privately owned rock wells and about 50 wells have been abandoned or never used because of low yields or high mineralization.

The larger water supplies available from the unconsolidated deposits in the buried Irondogenesee Valley have received increased attention in recent years. The sands and gravels of the main valley and its buried tributaries show the highest average yields in the area. Table 3 shows an average of $287 \mathrm{gpm}$ for 23 wells with a range from 10 to $1,016 \mathrm{gpm}$. Available evidence indicates that the total amount of ground water currently being taken from these deposits is only a small part of the large quantity available.

Still greater supplies of subsurface water are available by induced infiltration of water from Lake Ontario or from some of the larger streams. By artificially lowering the water table near surface waters, it may be possible to tap large supplies combining some of the favorable characteristics of both surface and ground water. Such water would be generally low in turbidity, pollution, and mineralization. It would show more uniform temperatures than surface water although varying more than ground water.

Thus, moderate to large amounts of water with widely varying physical and chemical qualities are available throughout most of the area. With a scientific program of development and operation, there is more than enough water to meet all forseeable future needs.

\section{SOURCES OF ADDITIONAL INFORMATION}

Inquiries relating to current water-resources information may be addressed to the following offices:

\section{SURFACE WATER:} Ithaca

Engineer in Charge

U. S. Geological Survey

702 First National Bank Building

Ithaca, New York

Albany District Engineer

U. S. Geological Survey

P. O. Box 948

Albany 1, New York

GROUND WATER: Albany

Geologist in Charge

U. S. Geological Survey

P. O. Box 590

Albany 1, New York

TOPOGRAPHIC MAPS:

( 20 cents each)

Director

U. S. Geological Survey

Washington 25, D. C.

\section{SELECTED BIBLIOGRAPHY}

Bonner, K. J., 1938, A Survey of the pollution of the surface waters of Monroe County, N. Y.: Monroe County Div. of Regional Plan., 19 pp., 6 maps (mimeo.), Rochester, N. Y.

Fairchild, H. L., 1935, Genesee Valley hydrography and drainage; Rochester Acad. Sci. Proc., vol. 7, no. 6, pp. 157-188. (Describes preglacial and glacial drainage of Genesee and Irondogenesee Valleys and resulting present-day surface and subsurface hydrologic conditions. Includes bibliography.)

Griswold, R. E., 1951, The ground-water resources of Wayne County, N. Y., Dept. Conserv., Water Power and Control Comm., Albany,. N. Y., Bull. G. W. 29 . 
Hartnagel, C. A., 1907, Geologic map of the Rochester and Ontario Beach quadrangles: New York State Mus. Bull. 114.

Hopkins, C. G., and Lozier, W. S., 1935, Report on obtaining a supplementary source of water supply for the city of Rochester, $32 \mathrm{pp}$. (mimeo.), Rochester, N. Y. (A detailed study of the unconsolidated deposits of the buried Irondogenesee Valley as a possible source for a municipal water supply: Well records, water analyses, and list of references included.)

Horton, R. E., consulting engineer, 1944, Report on proposed improvement and extension of Hemlock Lake water-supply system, Rochester, N. Y.: 58 pp., Vorheesville, N. Y.

Leggette, R. M. , Gould, L. O., and Dollen, B. H. , 1935, Ground-water resources of Monroe County, N. Y.: Monroe County Regional Plan. Board, 141 pp. (mimeo.), Rochester, N. Y. (Describes geologic and ground-water conditions by quadrangles and contains records of several thousand wells in Monroe County.)

National Board of Fire Underwriters, 1950, Report on the city of Rochester. Report 238.

New York State Department of Health, 1948, Public water-supply data for New York State, Bull. 19, Albany, N. Y.

U. S. Army, Corps of Engineers, 1944, Report on Genesee River, New York. 78th Cong., 2d sess., H. Doc. 615.

U. S. Geological Survey, issued annually, Surfacewater supply of the United States, Part 4, St. Lawrence River basin.

U. S. Lake Survey, 1950, Survey of northern and northwestern lakes, Bull. 59. 